商

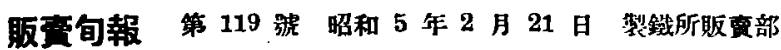

昭和 4 年の銅材供粭統計を見て

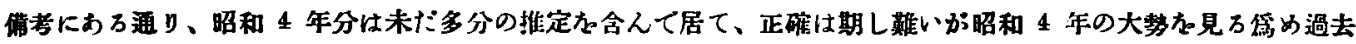

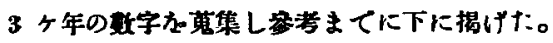

過去 3 ケ年鎆材供給 數量比較表單位䣩

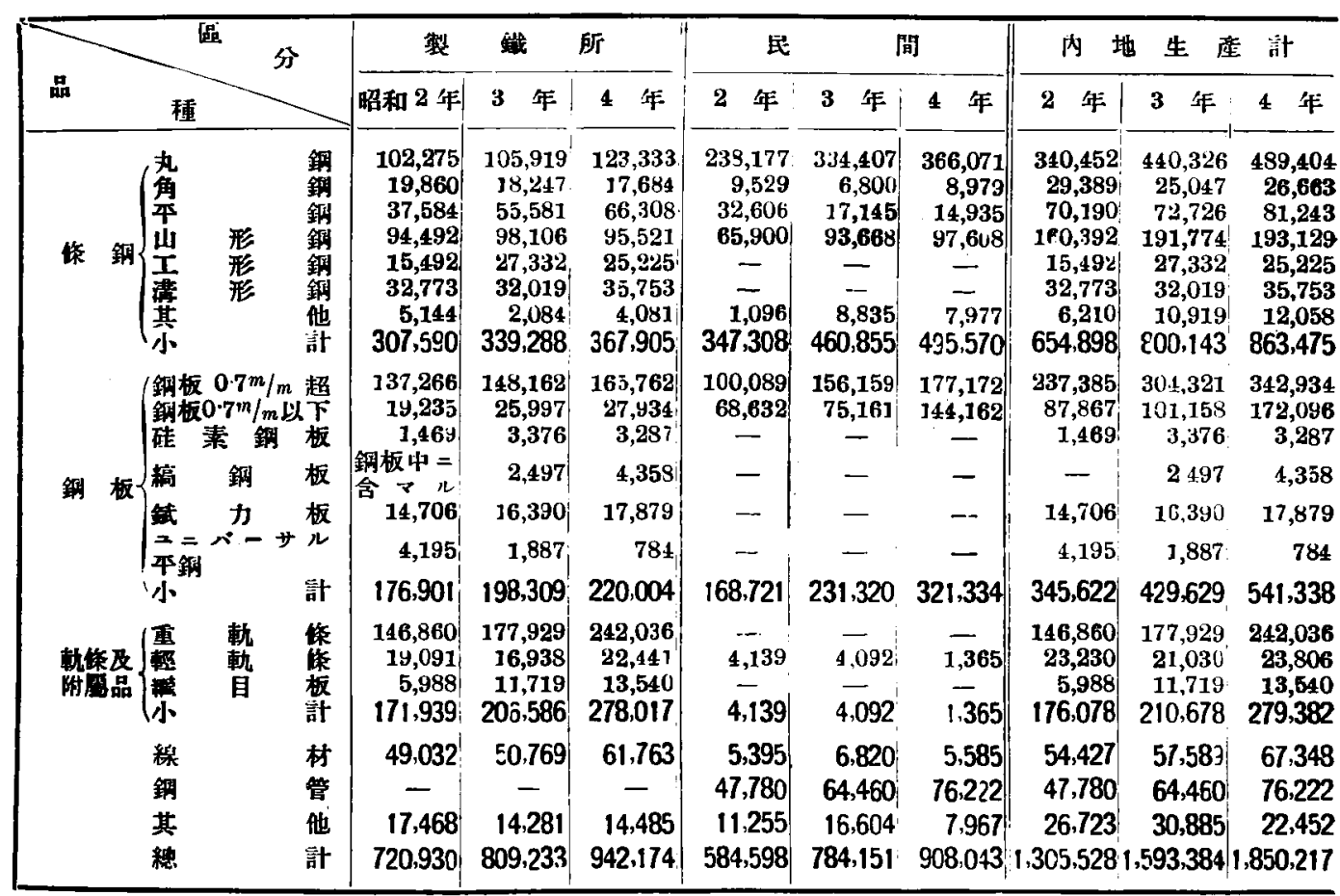

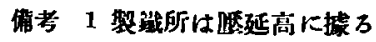

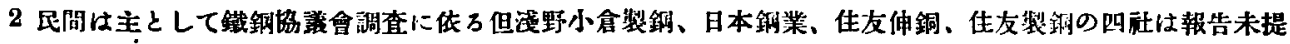

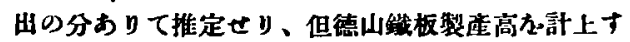

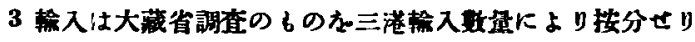

4「其他小忙主として車軸外輪及銀裂品とす

5 昭和 4 年分は正磪方缺くものあるる以て後に至り訂正することあるべし

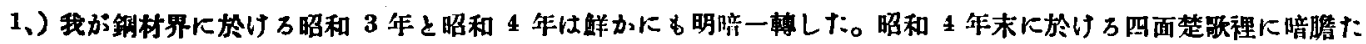

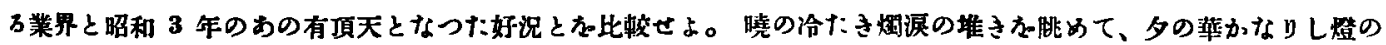
想及感がある。誠に夢に夢み万心持がせられろてはないか。

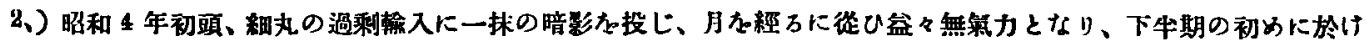

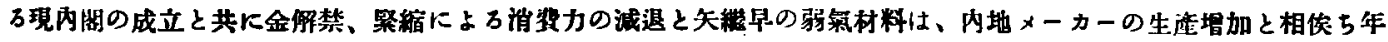

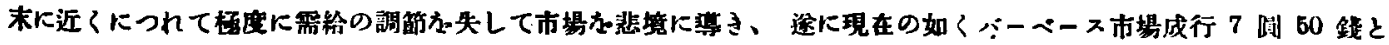




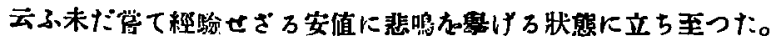

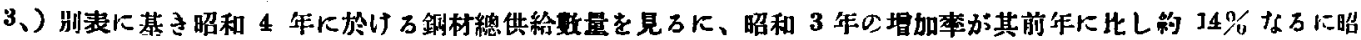

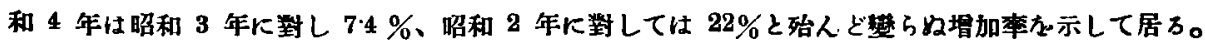

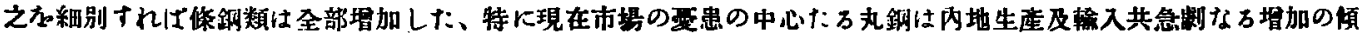

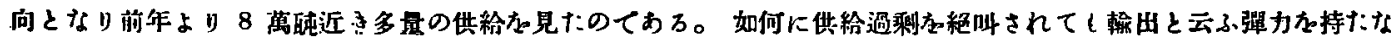

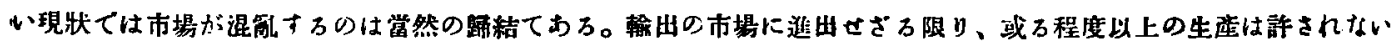

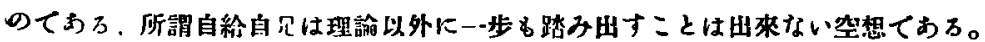

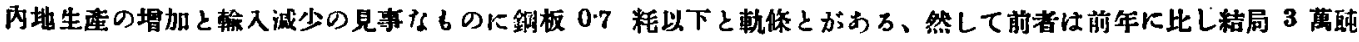

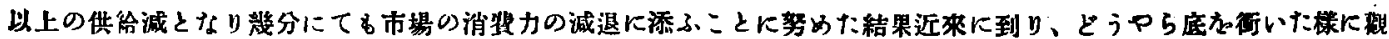

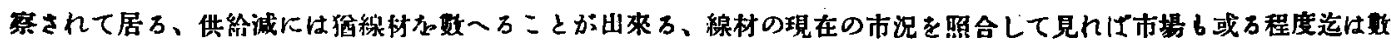
字に侤つて動くことが制取されよう。

\begin{tabular}{|c|c|c|c|c|c|}
\hline \multicolumn{3}{|c|}{ 入 } & \multicolumn{2}{|c|}{ 總 } & 就 \\
\hline 2 年 & 3 年 & 年 & 2 年 & 3 年 & 4 年 \\
\hline 230 & 43,538 & 10 & 397,682 & $\mathbf{4 8 3 , 8 6 4}$ & 14 \\
\hline 983 & $\begin{array}{r}5,830 \\
17,483\end{array}$ & $\begin{array}{l}741 \\
342\end{array}$ & 6,372 & 30,877 & a) \\
\hline $\mathbf{3 8 , 1 9 3}$ & 22,764 & 25,157 & $\begin{array}{r}8,344 \\
198,685\end{array}$ & $\begin{array}{r}90,209 \\
214,538\end{array}$ & $\begin{array}{r}98,085 \\
218,286\end{array}$ \\
\hline & 14,369 & 26,056 & 51,987 & 41,701 & 81 \\
\hline & 447 & 7 & & 1 & 6.50 \\
\hline 22,012 & 26,167 & 01 & 3,222 & 7,086 & 16 , \\
\hline 206,161 & 139,598 & 190,158 & 861,059 & 939,741 & 1,053 \\
\hline 49,562 & 69,873 & 57,183 & 286,947 & $\mathbf{3 7 4 , 2 9 4}$ & ou \\
\hline & & & 263,259 & & \\
\hline ,210 & 9,706 & 10,248 & 11,679 & 13,082 & 13 \\
\hline 4,512 & 7,677 & 2,690 & 4,512 & 10,17 & \\
\hline 61,052 & 72,113 & 81,564 & 75,758 & 88,503 & 99,44 \\
\hline - & - & - & 4,195 & 1,887 & 784 \\
\hline 300,728 & 342,937 & 231,558 & 646,350 & 772,566 & 772,896 \\
\hline 65,760 & 24,582 & 15,351 & 212,690 & 202,511 & 257,387 \\
\hline $\begin{array}{l}33,094 \\
4,096\end{array}$ & 20,870 & 18,133 & $\begin{array}{r}46,324 \\
70,084\end{array}$ & $\begin{array}{l}41,900 \\
16338\end{array}$ & 14,980 \\
\hline 92.950 & 50071 & 34,924 & 269,028 & 260,749 & 314,3 \\
\hline 109,086 & 172,644 & 157,474 & 163,513 & 230.233 & 224,822 \\
\hline 52,003 & 53.859 & 63.049 & 99.783 & 118.319 & 139,2 \\
\hline 4,729 & 4,935 & 5,052 & 31,515 & 35,820 & 27,504 \\
\hline 765,720 & 764,044 & 682,215 & & & 2,532 \\
\hline
\end{tabular}

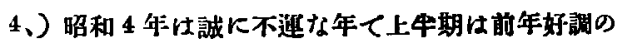

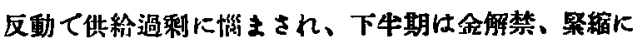

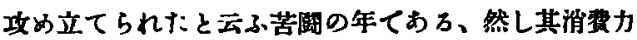
の娍退は下半期とは云ふいのの年末に近づてて渐く本

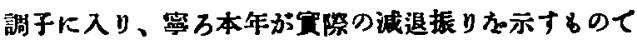
はあるまいか。斯く考察す万時は本年に於ける需給の 調節に對しては一層の戒心方裂するいのと思汢んる。

5.6月積先物值段協議會

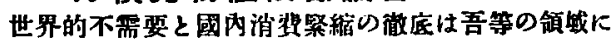
於ては斯業の生在取引界艻死線に㫷かもかの如く見之 万。2 月 8 日大阪に開加れたる協議會は極端的る消

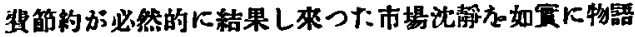
つて居る。

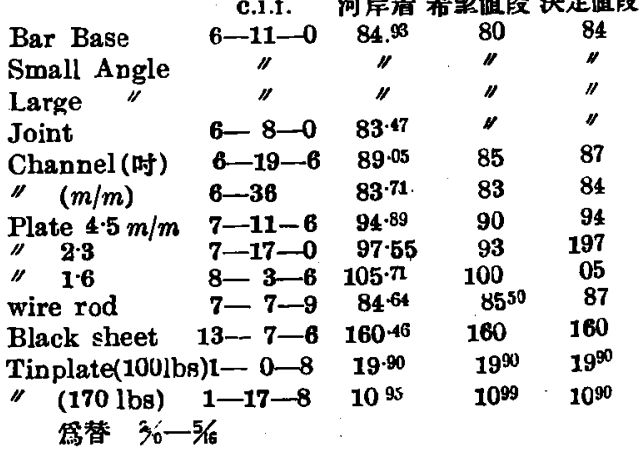

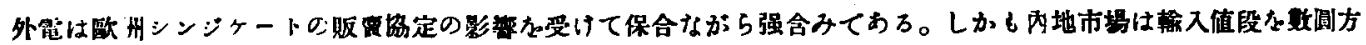

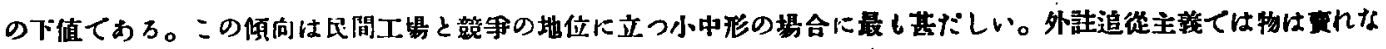

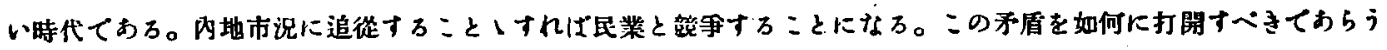
か。吾等の受難㬐代は將に第二期に入つたのてある。

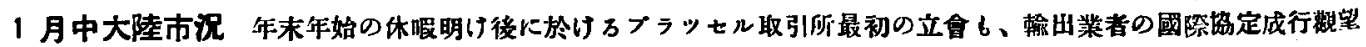

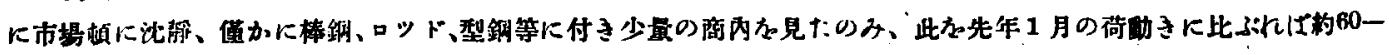

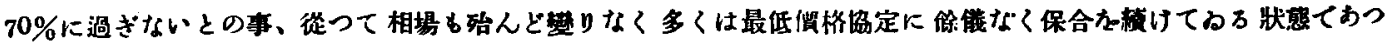

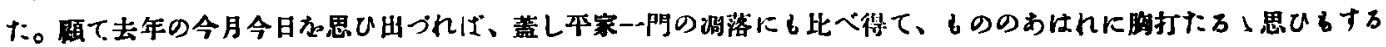

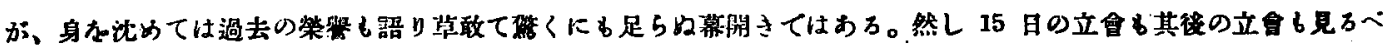

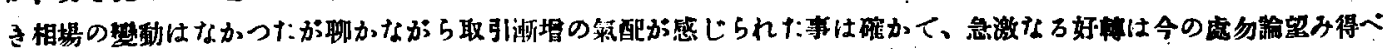




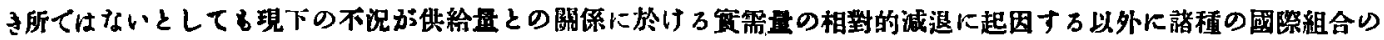

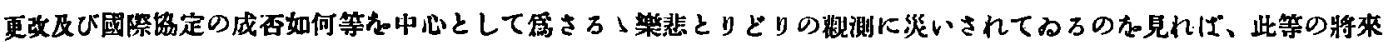
に於け万見極めが可能となり次第、市場は徐々に好轉して行くのてはあるまいかと想像される。

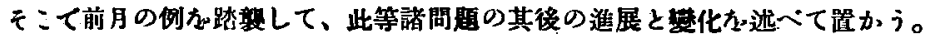

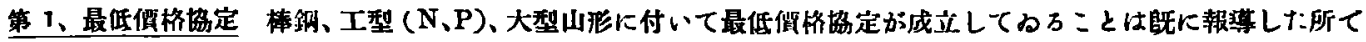

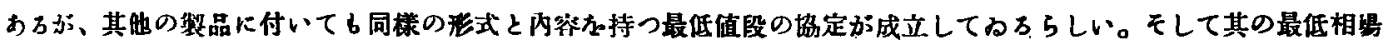

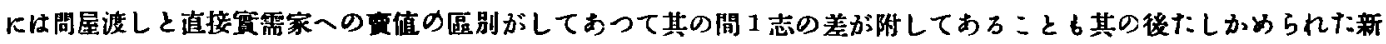
林料てあ万。即万

\begin{tabular}{|c|c|c|}
\hline 品 & 問属向 & 证接實需家向 \\
\hline 銅 & $5-5-0$ & $5-6-0$ \\
\hline$\%+2$ 吋 & $4-11-0$ & $4-12-0$ \\
\hline b ñ- & $4-12-0$ & $4-13-0$ \\
\hline タョイスト(N. P型) & $4-19-0$ & $5-0-0$ \\
\hline (B.S型) & $5-1-0$ & $5-2-0$ \\
\hline 山 型 & $5-5-0$ & $5-6-0$ \\
\hline 銅 & $6-4-0$ & - \\
\hline & $6-6-0$ & - \\
\hline
\end{tabular}

第2、國際共販組合 大陸メイカーの間に、共存共少の徹底

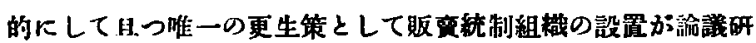

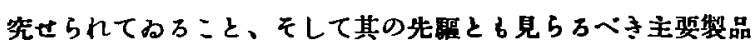
の輪出向註文配分事務所設置案の諳が可决せられたことは既に 報告した:通りておるが、其の後蒐策し得け材料方綜合すると、

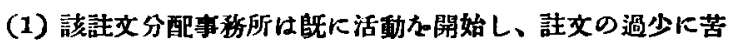

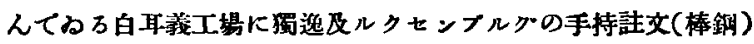
分興せられたと云はれてるら。然し其の詳細のニニースは未だ

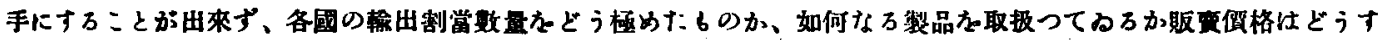
ろのか、等碓たることは云へはいが大體夯記の如く決定したらしい。

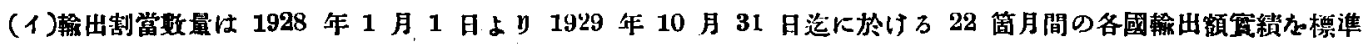

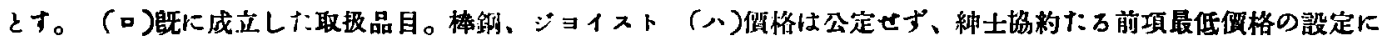

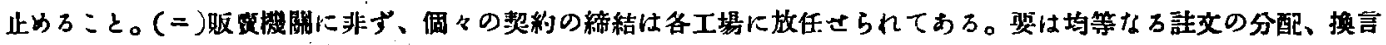

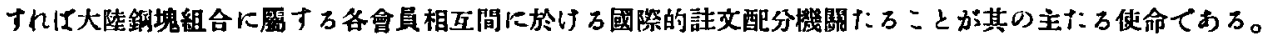

(2) 以.上は理想的施設としての國際共販組合が設置せらろいまて、6ケ月の期限各割して設けられた顿定的のいの

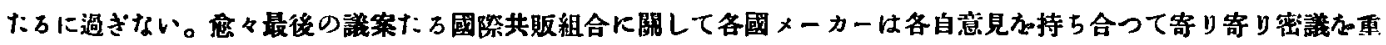

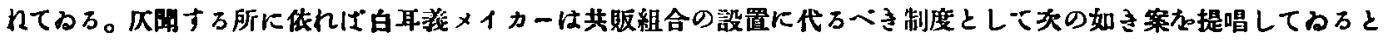

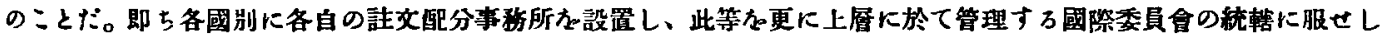

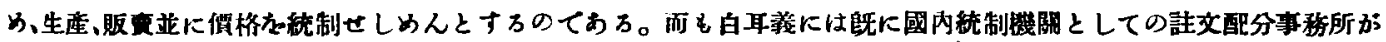

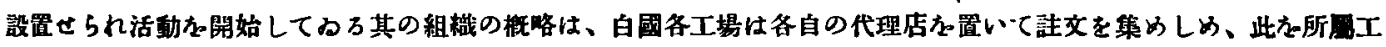

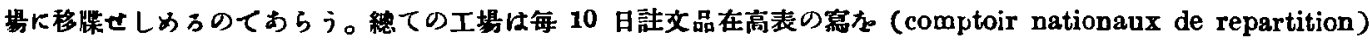

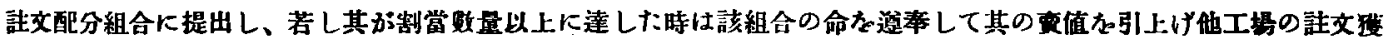

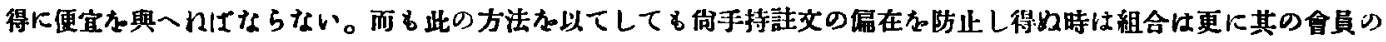

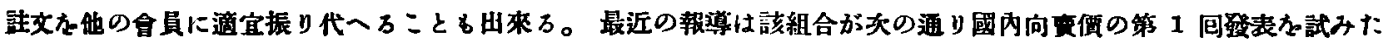
ことか等へた。

棒銅 940 法工形(N P) 935 法山形940法

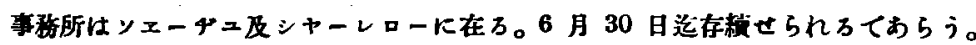

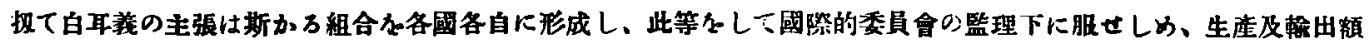

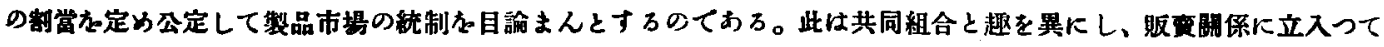

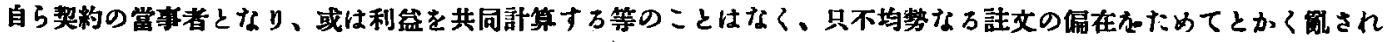

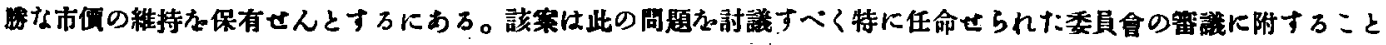

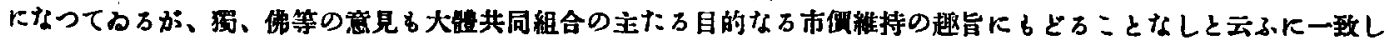

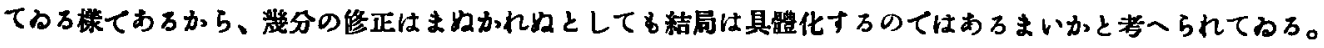

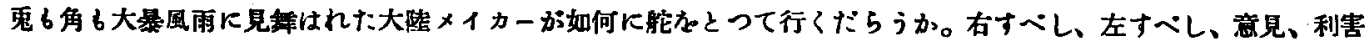

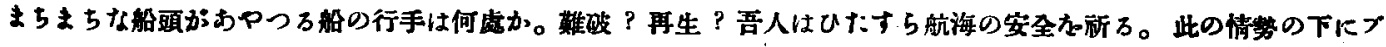

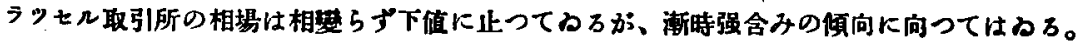




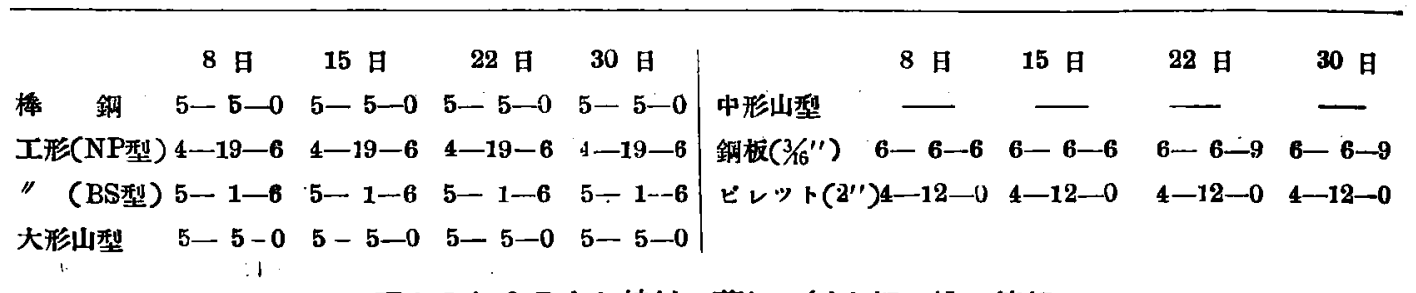

昭和 5 年 2 月中旬線材、薄板、錻力板。輸入速報

\begin{tabular}{|c|c|c|c|c|c|c|c|c|c|}
\hline \multirow{2}{*}{\multicolumn{2}{|c|}{ 區分 \品名 }} & & 線 柆 & & & \multicolumn{2}{|c|}{ 淢，板 } & \multicolumn{2}{|c|}{ 䤵力柜 } \\
\hline & & $\begin{array}{l}\text { B.W. } \\
\text { No. } 5\end{array}$ & 其 舵 & 詀 & 上中旬計 & 0.7 粍以下 & 上中旬計 & & 上中旬計 \\
\hline 咍 & F & 1,659 & 237 & $1.896^{2}$ & 4,014 & 276 & 848 & 368 & 928 \\
\hline 大 & 阪 & 243 & 611 & 854 & 854 & 178 & 515 & 828 & 903 \\
\hline 栱 & 嘴 & 151 & - & 151 & 251 & 591 & 1,069 & 1,411 & 2,425 \\
\hline & & 2,053 & 849 & 2,901 & 5,119 & 1.045 & 2,432 & 2,605 & 4,259 \\
\hline
\end{tabular}

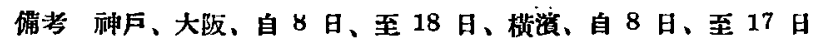

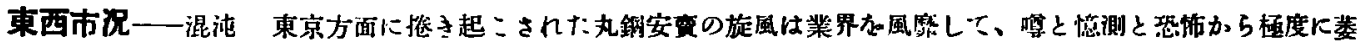

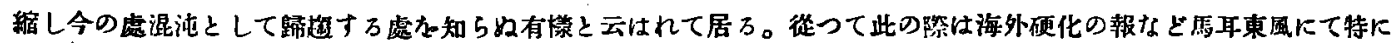

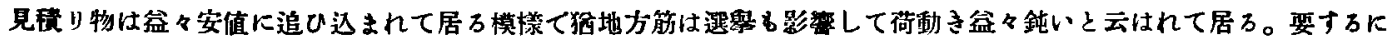

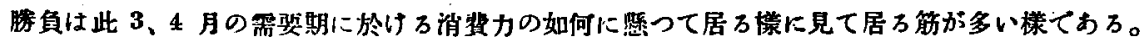

東 京市 況

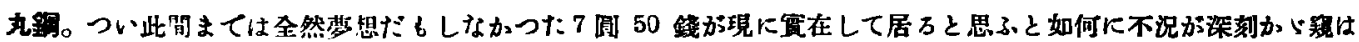

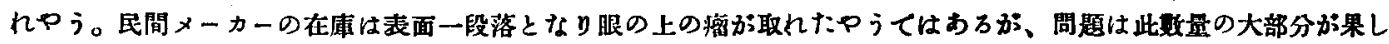
て今迄の吞ク玉の整理ておろかどうかにあつて、若し浮動物とはつて現はれることありとせは將來の生痤は㟙く借い

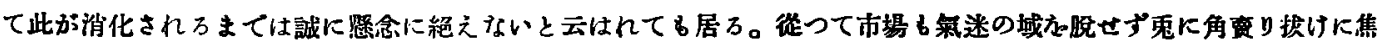
つて目先唒軟弱と見られて居ろ。

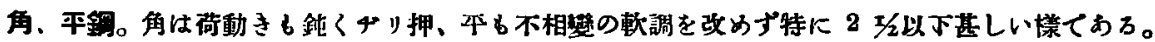

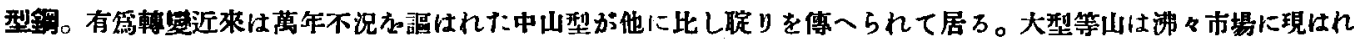

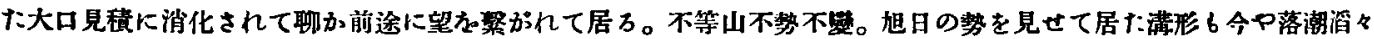
と $2 x / 2 \times 5,100 \times 59$ 枕か並べて崩落か見万に到つた。エ形る低迷して先行b期待薄。

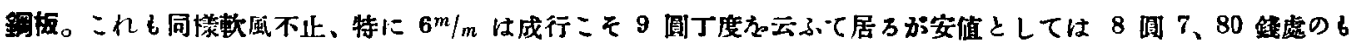

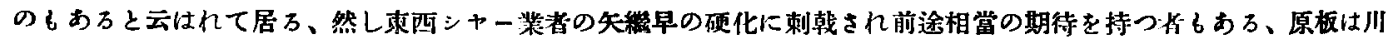
崎の 3 圆安と外註入荷期待に頍打ちとなつたが需給覞から相當底堅いと見られて居ろ。

大原市 況

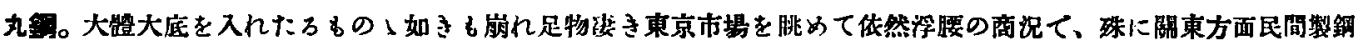

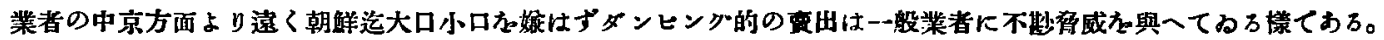

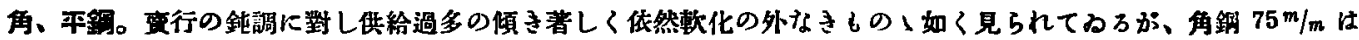

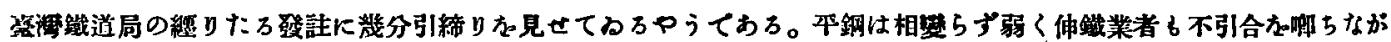
ら 10 鈛刻みに引落されてゃろ。

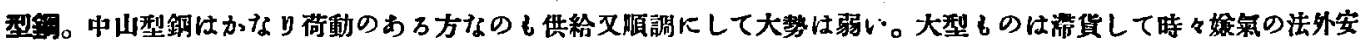

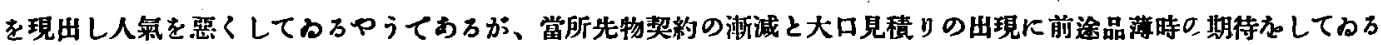

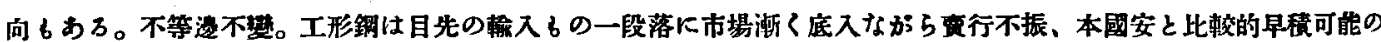

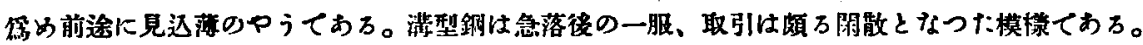

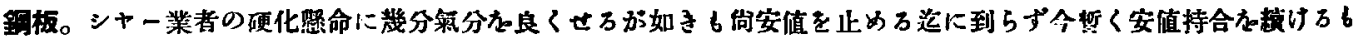
のと見られてゅろ。薄板市場は弱持合だと云はれてるる。

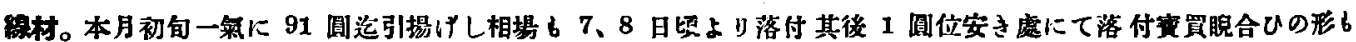

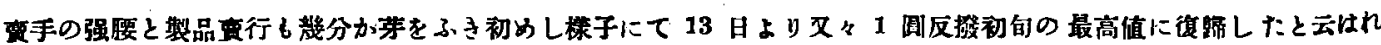


Tr万。

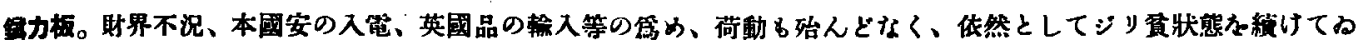
万。

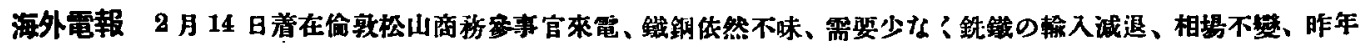

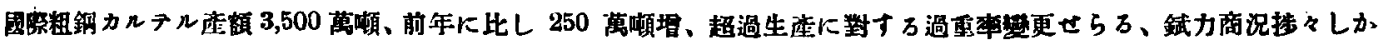
らナ゚、黑板需姴娍、相場何れ6保合ひ。

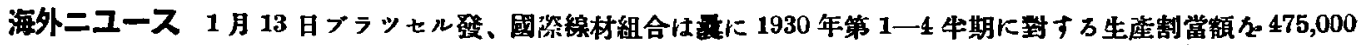

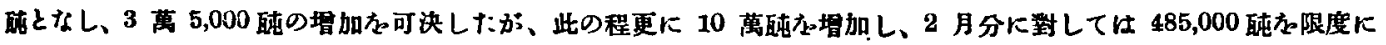

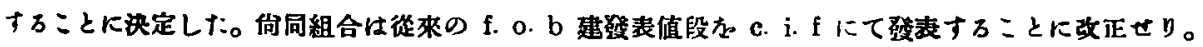

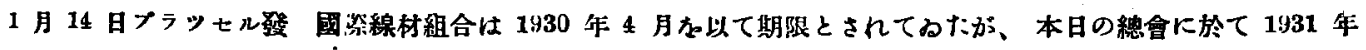
12 月 31 日迄存较に決定。

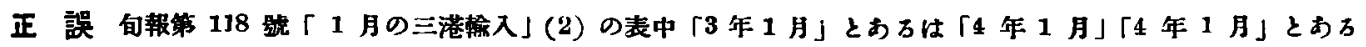
は「5 年 1 月小、同(3)の表中「昭和 4 年總計」とお万は「前年同期」の譟植に就き訂正す。

\section{外國雼替 市中相場}

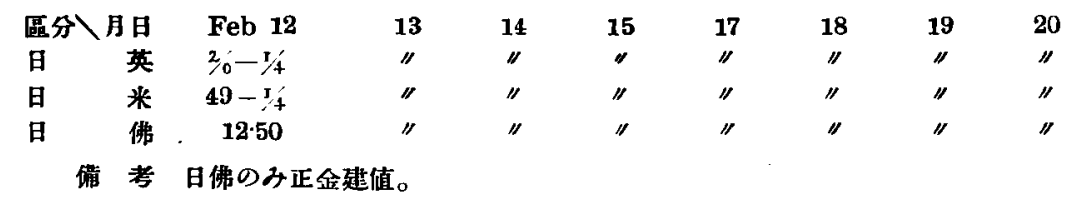

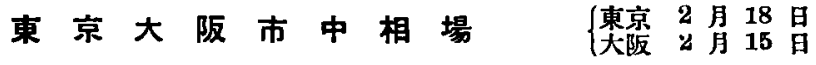

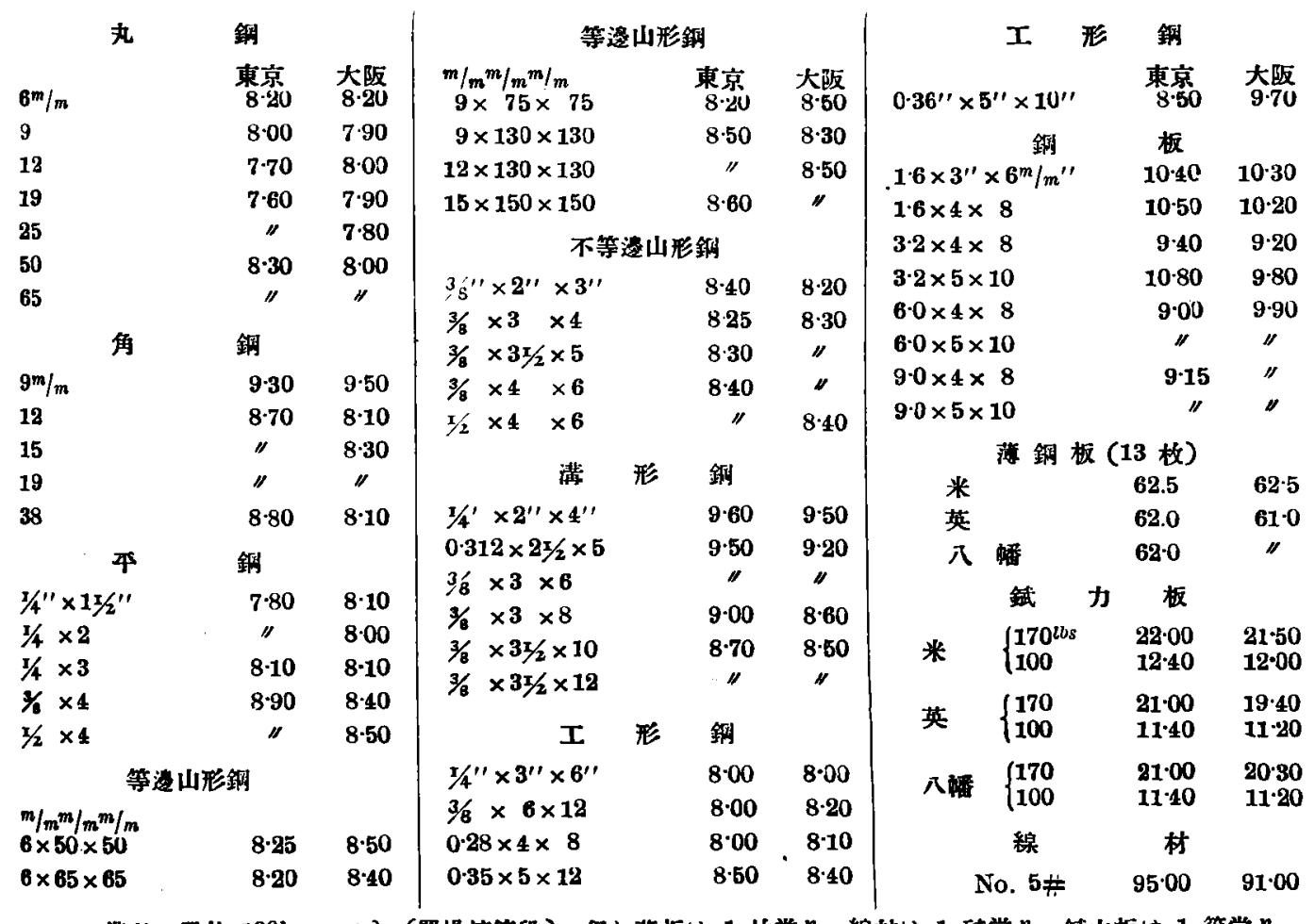

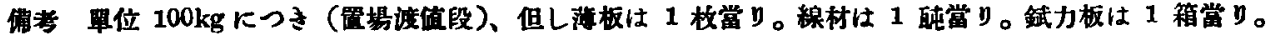




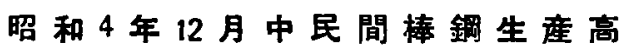

單位䣩

\begin{tabular}{|c|c|c|c|c|c|c|c|c|c|c|c|}
\hline 寸 法 & 䣩 數 & 寸 法 & 䣩 數 & 寸 法 & 酔 數 & 寸 法 & 䣩 数 & 寸 法 & 䣩 政 & 寸 法 & 䣩 数 \\
\hline 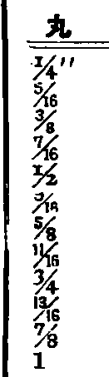 & $\begin{array}{r}r \\
94 \\
310 \\
2,747 \\
4 \\
2,669 \\
13 \\
4,736 \\
22 \\
5,645 \\
11 \\
2,430 \\
3,156\end{array}$ & $\begin{array}{l}11 / 8 \\
11 / 4 \\
13 / 8 \\
11 / 2 \\
15 / 8 \\
13 / 4 \\
17 \% 8 \\
23 \\
21 / 8 \\
21 / 4 \\
23 / 8 \\
21 / 2 \\
23 / 4\end{array}$ & $\begin{array}{r}833 \\
690 \\
330 \\
427 \\
233 \\
426 \\
229 \\
170 \\
59 \\
68 \\
4 \\
116 \\
2\end{array}$ & $\begin{array}{l}27 \% \\
378 \\
31 / 4 \\
31 / 2 \\
31 / 4 \\
4 \\
\text { 其. 他 }\end{array}$ & \begin{tabular}{r|}
70 \\
32 \\
37 \\
53 \\
22 \\
28 \\
465
\end{tabular} & $\begin{array}{c}\frac{\text { 角 }}{11 / 41} \\
13 / 4 \\
2 \\
21 / 2 \\
21 / 8-21 / 2 \\
25 / 8-3\end{array}$ & $\begin{array}{r}0 . \\
\mathbf{9 9} \\
\mathbf{3 6 8} \\
335 \\
\mathbf{2 5 3} \\
\mathbf{3 6} \\
4\end{array}$ & 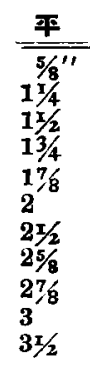 & $\begin{array}{r}54 \\
115 \\
33 \\
34 \\
46 \\
32 \\
170 \\
5 \\
23 \\
2 \\
2\end{array}$ & 其 他 & 1,411 \\
\hline
\end{tabular}

昭和 5 年 1 月當所整品揚地別搏送高

單位酥

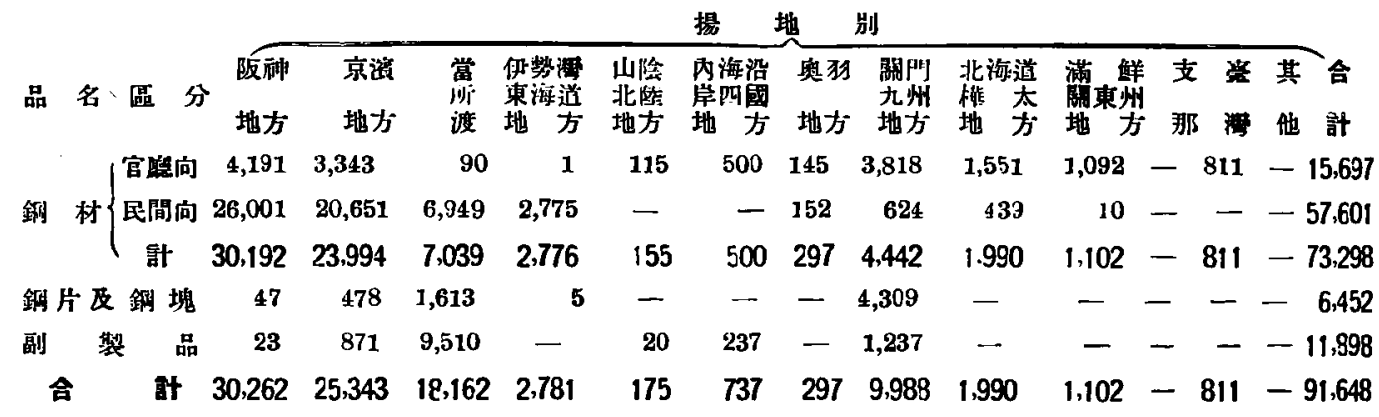

肘雷旬報第 120 號炤和 5 年 3 月 1 日

製䤦所販尧部

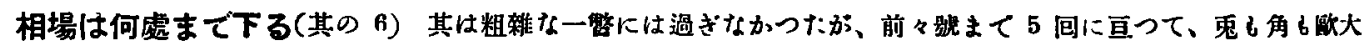

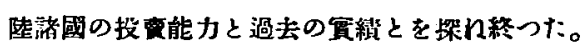

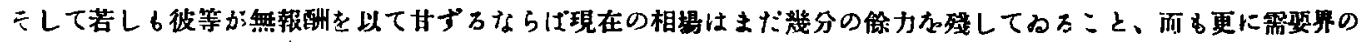

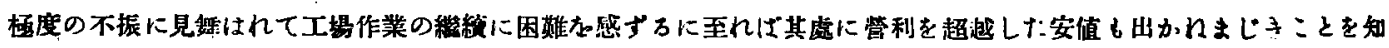

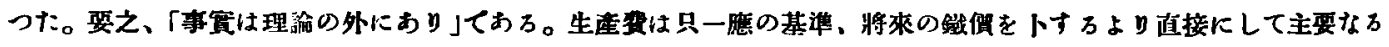

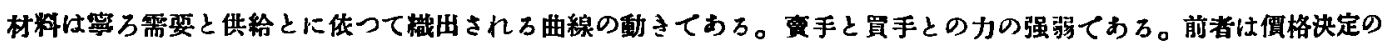
量的方面よりす万概測ており、後者は筫的方面よりす万判断てお万。

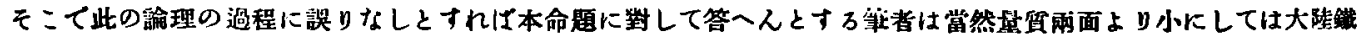

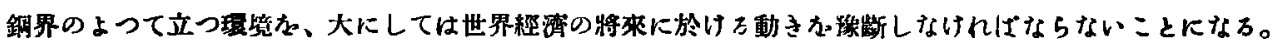

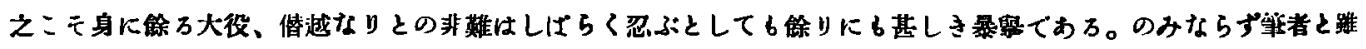

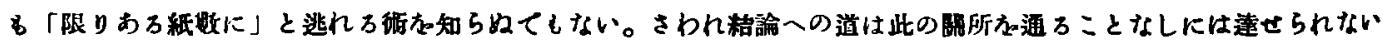
重盛は遂に中成の道を見出した。

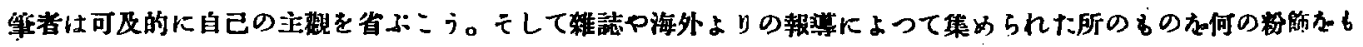

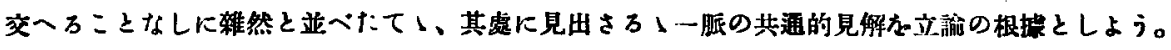

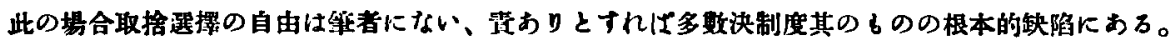

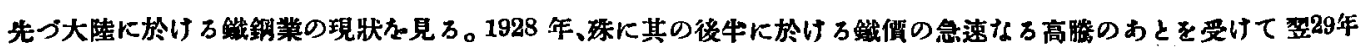

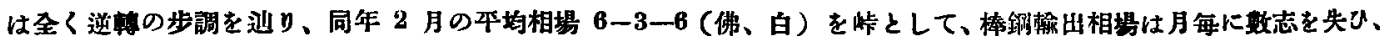

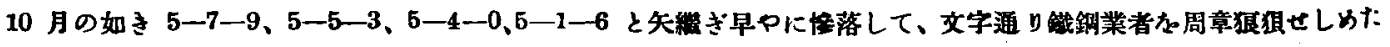

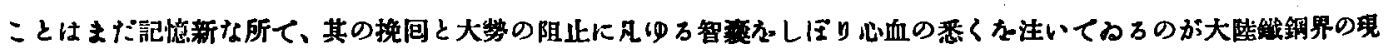

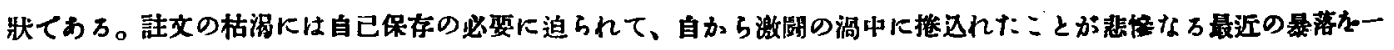




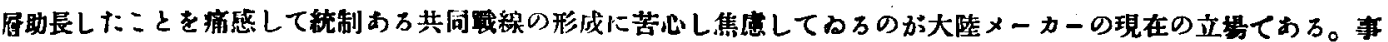
此虔に至つた事情は十にして足りない。

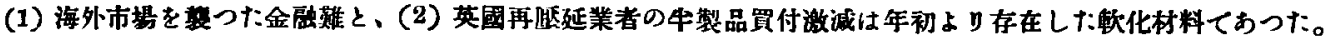

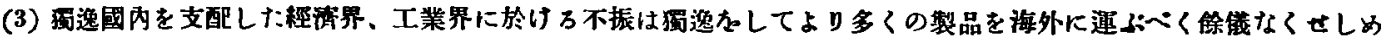

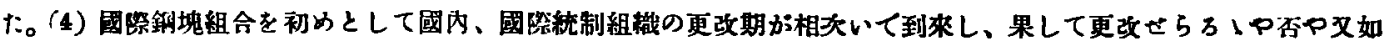

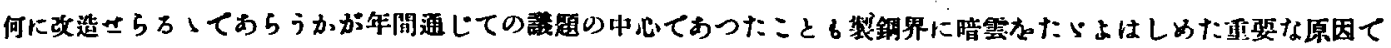

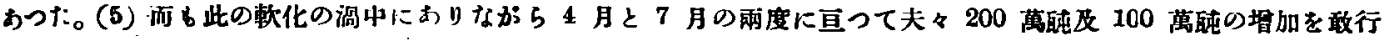

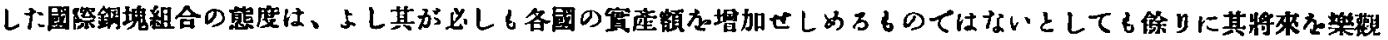

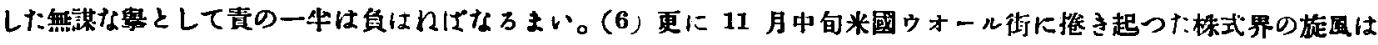

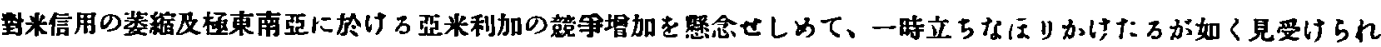

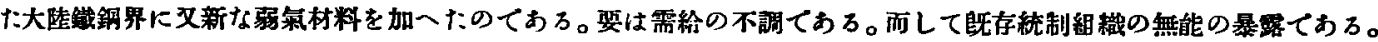

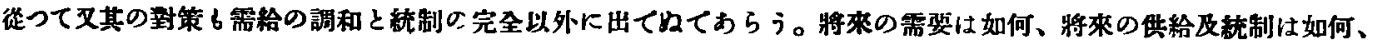

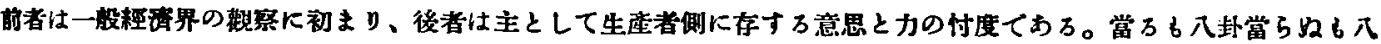

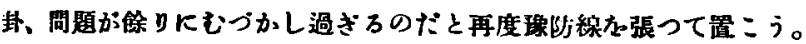

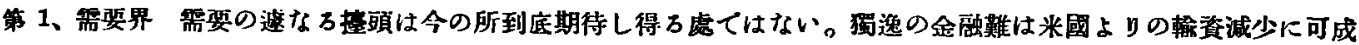

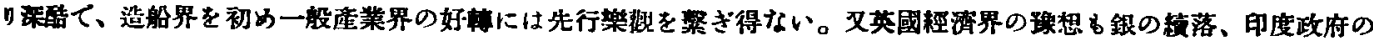

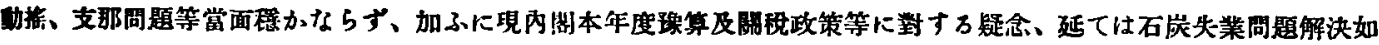

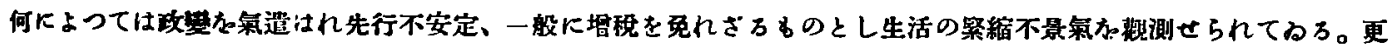

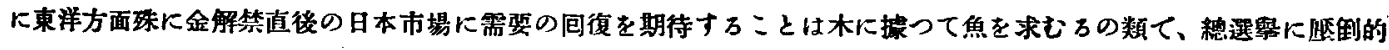

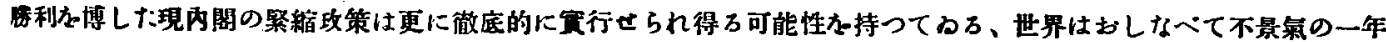
各迼らればはるまい。

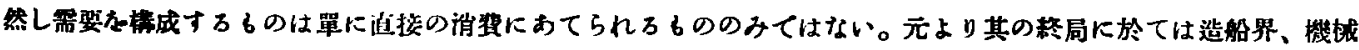

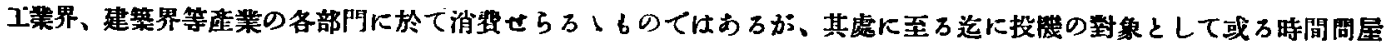
の會庫に在庫品として满へられて居万部分がまる。

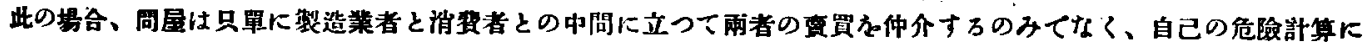

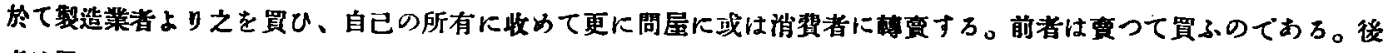

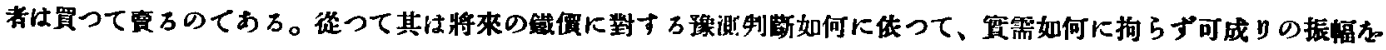
以て浮動す万。

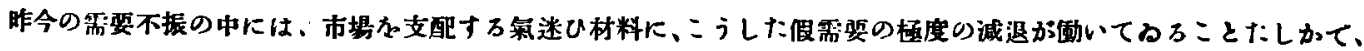

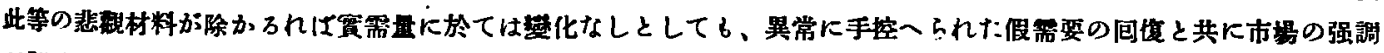

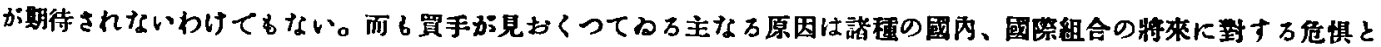

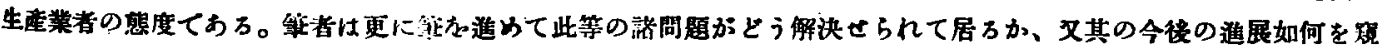
はИばならない(粮く)

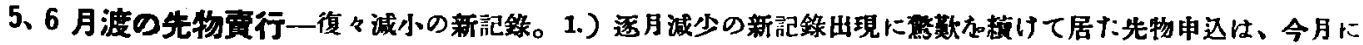

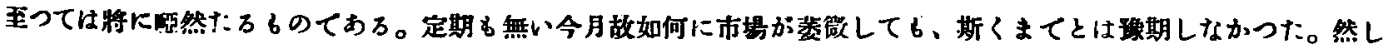

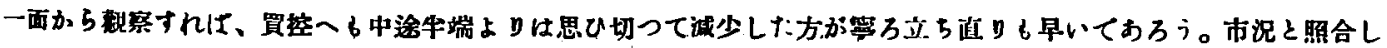

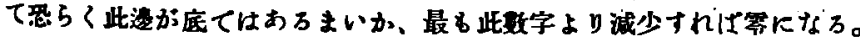

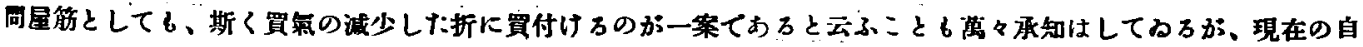

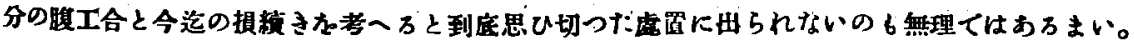

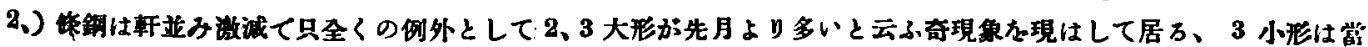

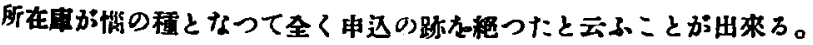

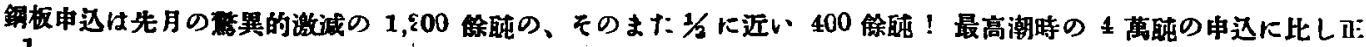

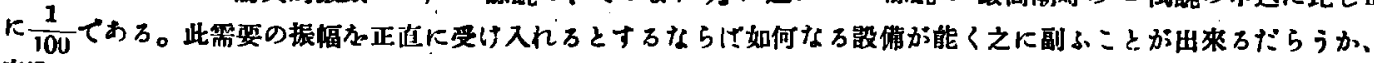

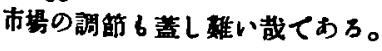




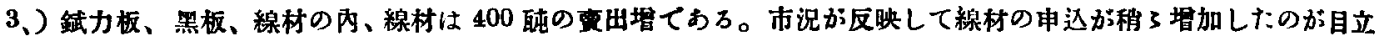
つて居る。

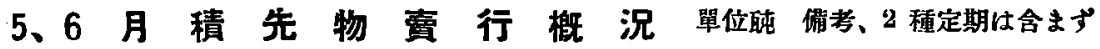

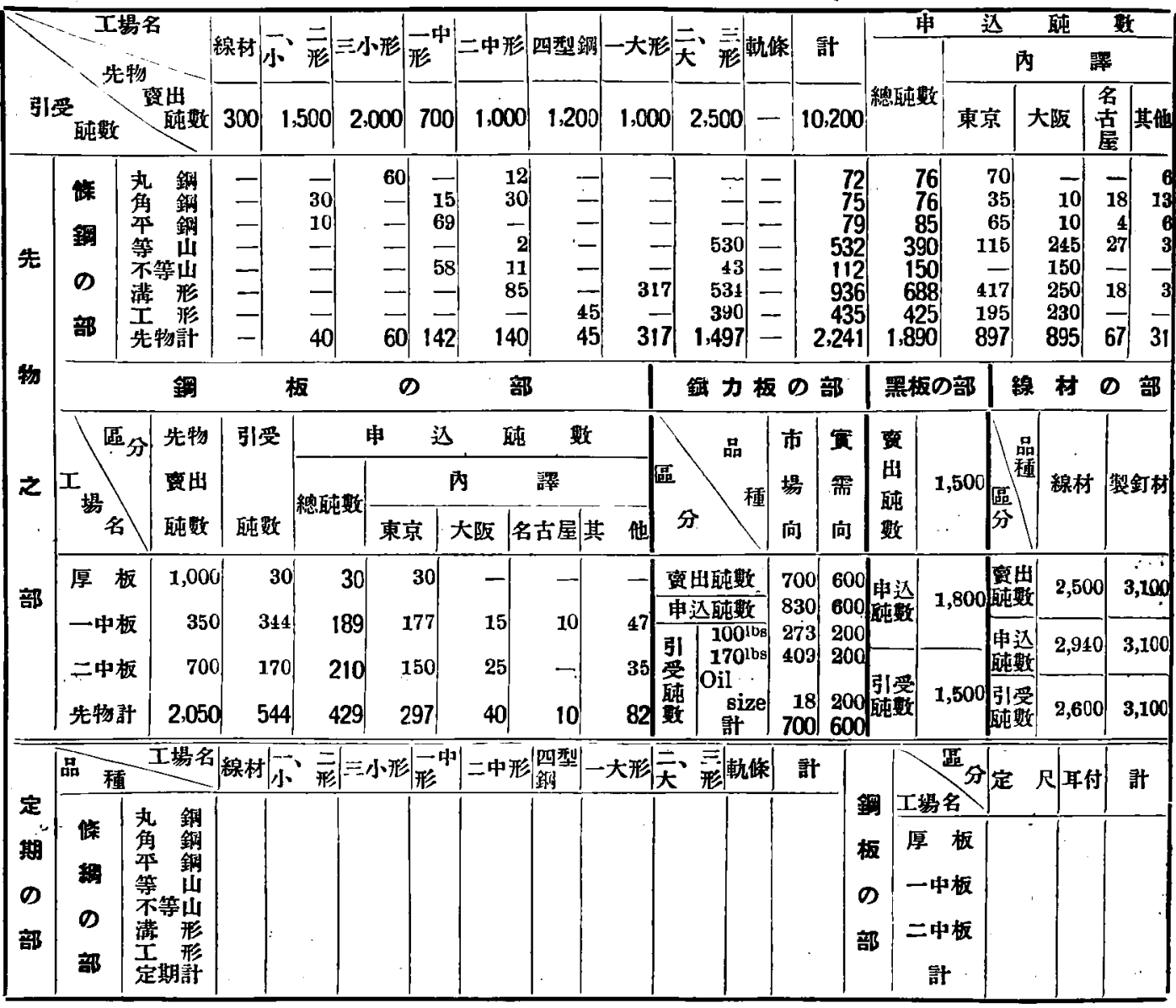

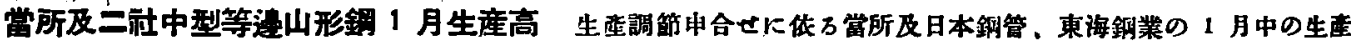

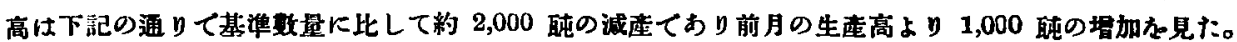

$\begin{array}{lcllllll}53^{m} / m & 60 \mathrm{~m} / m & 65^{\mathrm{m}} / \mathrm{m} & 70^{\mathrm{m}} / \mathrm{m} & 75^{\mathrm{m}} / \mathrm{m} & 90^{\mathrm{m} / m} & 100^{\mathrm{m}} / \mathrm{m} & \text { 計 } \\ 1,911 & 3 & 2,733 & 47 & 1,554 & 1,156 & 1,361 & 8,765\end{array}$

昭和 5 年 2 月中線材、薄板、鉶力板、輸入速報

\begin{tabular}{|c|c|c|c|c|c|c|c|c|c|}
\hline \multirow{2}{*}{\multicolumn{2}{|c|}{ 㗐分 \品名 }} & \multicolumn{4}{|c|}{ 總，村 } & \multicolumn{2}{|c|}{ 落桭 } & \multicolumn{2}{|c|}{ 国力板 } \\
\hline & & $\begin{array}{l}\text { R. } \\
\text { No. }\end{array}$ & 其 件 & 就 & 2月中計 & 0.7 粍以下 & 2 月中計 & & 月中中恠: \\
\hline 神 & F & 233 & 302 & 335 & 4,349 & 133 & 981 & 528 & 1,416 \\
\hline 大 & 阪 & 330 & 102 & 432 & 1,286 & 467 & 982 & 213 & 1,1 tg \\
\hline 柫 & 溜 & 252 & 104 & 356 & 607 & 470 & 1.539 & 834 & 3,259 \\
\hline & & 815 & 308 & 1,123 & 6,242 & 1,070 & 3,502 & 1,575 & 5,834 \\
\hline
\end{tabular}

储考、部戶、大阪、自 19 日至 26 日、横溢、自 18 日、王 25 日 
昭和 5 年 1 月中神戸、大阪、横潧、三港輸入鎆材品種寸法別數量表

\begin{tabular}{|c|c|c|c|c|c|c|c|c|c|c|c|}
\hline 寸法 & 䎲 数 & 寸法 & 䣩 数 & 寸法 & 㑕 數 & 寸 法 & 㳳 数 & 寸 法 & 䣩 数 & 寸法 & 䣩 \\
\hline 0 & 1 部 & $81 / 4$ & 10 & 44 & 5 & \multicolumn{2}{|c|}{ 型銅 $/$ 部 } & & $x$ & $1 x / 2$ & \\
\hline 丸 & 銓 & $\begin{array}{l}83 / 2 \\
9^{2}\end{array}$ & $\begin{array}{r}\mathbf{9} \\
\mathbf{2 5}\end{array}$ & 75 & 8 & \multicolumn{2}{|c|}{ 等逶山形鐦 } & $\begin{array}{r}6 \times 3 \\
6 \pm / 2 \times 3\end{array}$ & $\begin{array}{l}10 \\
30\end{array}$ & $\left|\begin{array}{c}2 \times 2 \\
2 r / 2 \times 25 / 2\end{array}\right|$ & $\begin{array}{r}59 \\
5\end{array}$ \\
\hline $36^{\prime \prime}$ & & $93 / 2$ & y & 影 & 590 & $34^{\prime \prime}$ & 60 & $7 \times 3$ & 13 & $3 \times 3$ & 46 \\
\hline $\begin{array}{l}16 \\
1 / 4 \\
5\end{array}$ & 83 & ${ }_{10}^{91 / 16}$ & $\begin{array}{r}1 \\
67\end{array}$ & 平 & 銅 & 74 & 151 & $\begin{array}{l}7 \times 31 / 2 \\
8 \times 3\end{array}$ & $\begin{array}{r}7 \\
20\end{array}$ & $\begin{array}{l}4 \times 4 \\
5 \times 4\end{array}$ & $\begin{array}{r}33 \\
5\end{array}$ \\
\hline $\begin{array}{l}5 / 6 \\
1 / 1 / 2\end{array}$ & $\begin{array}{r}65 \\
1\end{array}$ & 11 & 6 & 3/8" & 36 & $1 / 4$ & $\begin{array}{l}206 \\
620\end{array}$ & $8 \times 31 / 2$ & 5 & $6 \times 3$ & 3 \\
\hline $3 / 8$ & 163 & $\begin{array}{l}12 \\
7.5 \mathrm{~m} / \mathrm{m}\end{array}$ & $\begin{array}{l}29 \\
30\end{array}$ & 5 & 140 & $\begin{array}{l}11 / 2 \\
13 / 4\end{array}$ & $\begin{array}{r}020 \\
92\end{array}$ & $8 x / 2 \times 3 x / 2$ & $\begin{array}{r}37 \\
7\end{array}$ & & \\
\hline $\begin{array}{r}13 / 32 \\
7 / 7\end{array}$ & 1 & $\begin{array}{l}7.5 \mathrm{~m} / \mathrm{m} \\
9\end{array}$ & $\begin{array}{r}30 \\
447\end{array}$ & 3 & $\begin{array}{l}108 \\
27 \pm\end{array}$ & 2 & 60 & $\mid \begin{array}{r}9 \times 3^{1} / 2 \\
9 x / 2 \times 3^{\pi} / 2\end{array}$ & $\begin{array}{l}7 \\
2\end{array}$ & 許 & 191 \\
\hline 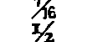 & $\begin{array}{r}2 \\
65\end{array}$ & 19 & 132 & 78 & 33 & $1 / 2$ & $\begin{array}{r}10 \\
295\end{array}$ & $10 \times 31 / 2$ & 3 & バイリン & グシート \\
\hline $17 / 3:$ & 3 & 22 & 31 & 1 & 79 & $3^{I} / 2$ & 243 & $12 \times 31 / 2$ & 1 & & \\
\hline $5 / 8$ & 73 & $\begin{array}{l}\mathbf{2 5} \\
\mathbf{3 3}\end{array}$ & $\begin{array}{r}15 \\
5\end{array}$ & $\begin{array}{l}1 / 4 \\
1 \leq 2\end{array}$ & $\begin{array}{l}70 \\
97\end{array}$ & & 74 & 計 & 144 & 計 & 1,532 \\
\hline 学 & $\begin{array}{r}10 \\
7\end{array}$ & 60 & 42 & $13 / 4$ & 109 & $1 / 2$ & $\begin{array}{r}2 \\
11\end{array}$ & 工 形 & 銅 & & \\
\hline $3 / 4$ & 72 & 130 & 1 & $17 \%$ & $\begin{array}{r}1 \\
09\end{array}$ & & 239 & $5 \prime \prime \times 3 \prime \prime$ & 97 & 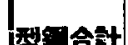 & 8377 \\
\hline 彎 & 18 & 計 & 3,123 & $2 \pi / 4$ & $\begin{array}{r}109 \\
12\end{array}$ & $15: m / m$ & 41 & $\begin{array}{r}5 \times 4 / 2 \\
5 \times 4\end{array}$ & $\begin{array}{l}27 \\
18\end{array}$ & 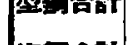 & ONד \\
\hline 瓷 & $\begin{array}{r}148 \\
3\end{array}$ & & & $2 \pi / 2$ & 116 & 200 & 192 & $8 \times 4$ & 41 & 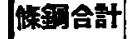 & 14,415 \\
\hline$\$ 2$ & 44 & （造船） & 材料） & & 42 & 計 & 2,396 & $8 \times 5$ & 79 & & \\
\hline 11 & 16 & 年, & 6 & $\begin{array}{l}358 \\
6\end{array}$ & $\begin{array}{l}30 \\
25\end{array}$ & (滥船) & 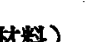 & $\begin{array}{r}8 \times 6 \\
10 \times 5\end{array}$ & 130 & 鍒板 & ，部 \\
\hline $\mathbf{1}^{\hat{1}}$ & $\begin{array}{r}2 \\
28\end{array}$ & $1^{15}$ & 15 & $6 \pi / 2$ & 3 & & & $\begin{array}{l}10 \times 0 \\
10 \times 6\end{array}$ & $\begin{array}{l}58 \\
183\end{array}$ & 鍃板 0. & 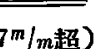 \\
\hline 15 & 6 & $\begin{array}{l}134 \\
2314 \\
13\end{array}$ & $\begin{array}{l}7 \\
2\end{array}$ & $71 / 2$ & 10 & $23^{2} / 2$ & ${ }_{10}^{2}$ & $12 \times 5$ & 304 & 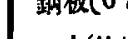 & / \\
\hline 1 & 1 & $\begin{array}{l}274 \\
21 / 2\end{array}$ & 1 & $\begin{array}{c}8 \\
9\end{array}$ & $3 i$ & $3 \pi / 2$ & 141 & $12 \times 6$ & 452 & '湢' & 1,136 \\
\hline 12 & 4 & $25 \%$ & 72 & 10 & $\begin{array}{r}31 \\
1\end{array}$ & 4 & 97 & & 69 & $8 z$ & $\begin{array}{l}396 \\
875\end{array}$ \\
\hline 13 & 47 & $23^{\circ}$ & 1 & 11 & 1 & $4 \mathrm{r} / 2$ & 18 & 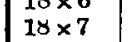 & 290 & $\begin{array}{l}38 \\
36\end{array}$ & 177 \\
\hline $\begin{array}{l}19 \\
13\end{array}$ & $\begin{array}{r}9 \\
10\end{array}$ & 27.8 & $\begin{array}{r}82 \\
2\end{array}$ & 12 & 135 & 6 & $\begin{array}{l}21 \\
48\end{array}$ & $18 \times 18$ & 23 & $1 / 4$ & 198 \\
\hline 17 & 5 & $34^{m} / m$ & 11 & 13 & $\begin{array}{r}46 \\
7\end{array}$ & 計 & 337 & & 83 & 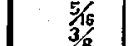 & $\begin{array}{r}67 \\
355\end{array}$ \\
\hline $1^{15 / 32}$ & $\begin{array}{r}2 \\
16\end{array}$ & 計 & 199 & $\begin{array}{l}14 \\
15\end{array}$ & $\begin{array}{l}7 \\
9\end{array}$ & st & 2732 & $\begin{array}{l}24 \times 7 \\
24 \times 71 / 2\end{array}$ & $\begin{array}{l}121 \\
48\end{array}$ & $7 / 8$ & 810 \\
\hline 13 & 16 & st & 3.322 & 36 & 62 & 訳 & 2,133 & 34 & 2015 & $Y_{6}$ & - \\
\hline $\mathbf{1}$ & 6 & ET & $3,3<2$ & 20 & 5 & 不等港卜 & 山形銅 & 竚 & $<, 240$ & & 40 \\
\hline & 42 & 角 & 銅 & 21 & 12 & $2 x / 11 x>0$ & & 满 & 铜 & w.G.No. & \\
\hline 1 & 11 & 3is" & 22 & 24 & 28 & $3 \times 21 / 2$ & 2 & $3 \times z^{\prime \prime} \times 2^{\prime \prime} 1$ & 16 & 11 & \\
\hline 12 & 21 & $1 / 4$ & 20 & 27 & 38 & $4 \times 3$ & 22 & $4 \times 1^{58}$ & $=0$ & & $\mathbf{3}$ \\
\hline 15 & $\mathbf{1}$ & 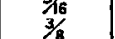 & $\begin{array}{l}18 \\
30\end{array}$ & $55^{m} / m$ & 17 & & 20 & 4 & 1 & 13 & 13 \\
\hline 5 & 29 & $\pi / 2$ & 14 & & 23 & $5 x$ & 206 & $5 \times 1^{75}$ & 50 & $143 / 2$ & \\
\hline $2 \pi$ & 31 & $5 / 8$ & 3 & 計 & 1,855 & $\begin{array}{l}5 \times \\
5 x\end{array}$ & $\begin{array}{l}199 \\
8\end{array}$ & $\begin{array}{l}5 \times 2 \times 1 / 2 \\
8 \times 33 / 2\end{array}$ & 77 & 15 & $\begin{array}{r}195 \\
21\end{array}$ \\
\hline 2 & $\begin{array}{l}10 \\
\mathbf{3 8}\end{array}$ & $1^{6}$ & 10 & （涉船 & 杜料) & $6 x$ & 44 & $10 \times 3 x / 2$ & 29 & & 75 \\
\hline $2^{1 / 2}$ & $\begin{array}{l}38 \\
29\end{array}$ & 13/3 & 1 & & & $6 \times 3 x / 2$ & 38 & $10 \times 4$ & 23 & 7 & 28 \\
\hline 2 & 1 & 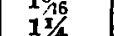 & 13 & 2 & 1 & $6 x$ & 113 & $12 \times 31 / 2$ & 206 & 18 & 72 \\
\hline & 27 & 12 & 17 & & $?$ & $7 \times 3 / 2$ & 1 & $15 \times 4$ & 75 & 9 & \\
\hline & 21 & $1 \frac{3}{4}$ & 2 & & & 計 & 672 & $\left|\begin{array}{cc}m / m & m / m \\
100 & 50\end{array}\right|$ & 101 & 31 & 4 \\
\hline 3. & $\begin{array}{r}25 \\
3\end{array}$ & 2 & 3 & 許 & 1,857 & （浩船 & 阵料) & $300 \times 100$ & 60 & 22 & 14 \\
\hline & 19 & 3 & 6 & 牛 俱 & 11 全同 & & & 击 & 690 & & \\
\hline & 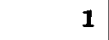 & $3 / 2$ & 24 & (洗) & 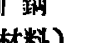 & $3 " \times 5 / 2 " \mid$ & 1 & iT & 690 & $1^{1} \cdot \bar{x}$ & 56 \\
\hline 4 & 16 & 4 & 20 & & 何科了 & $5 \times$ & 4 & （造船标 & 材料） & 1.8 & 2 \\
\hline $\begin{array}{l}41 / \\
4\end{array}$ & $\begin{array}{r}89 \\
153\end{array}$ & $51 / 2$ & $\begin{array}{l}77 \\
75\end{array}$ & st 1 & 6 & & 42 & $8^{\prime \prime} \times$ & 4 & 8.5 & 17 \\
\hline & 57 & $5^{1 / 2}$ & 56 & & 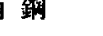 & & 1 & & 2 & 4.5 & 00 \\
\hline 5 & 166 & 6 & 16 & 計 1 & 35 & $6 \times 31 / 2$ & 47 & $10 \times 31 / 2$ & $=$ & $12^{m}$ & \\
\hline $51 / 4$ & $\begin{array}{l}17 \\
76\end{array}$ & $8^{m} / m$ & 21 & 八解 & 銅 & $\mid \begin{array}{l}7 \times 5 / 2 \\
\text { 言十 }\end{array}$ & $\begin{array}{r}32 \\
129\end{array}$ & $15 \times 6$ & 30 & $40^{\prime m}$ & 10 \\
\hline & 156 & 9 & 20 & 許 & 224 & 数 & 801 & וT & $4 !$ & .30"' & \\
\hline $6 \mathrm{~J} / 4$ & 34 & 12 & 5 & 其他， & 棒銅 & & & & |ST & 38 & 17 \\
\hline & $\begin{array}{l}56 \\
54\end{array}$ & 2 & 6 & & 1 & 球山？ & 㣌铜 & 丁 形 & 钢 & $\cdot 46$ & 10 \\
\hline & 7 & 3 & 8 & & & (i) & & & & & \\
\hline 8 & 81 & 38 & 11 & 合 & 6,038 & $5 / \times 3$ & 5 & $1 \times 1$ & 10 & 业 & 4,934 \\
\hline
\end{tabular}




\begin{tabular}{|c|c|c|c|c|c|c|c|c|c|c|c|}
\hline 寸法 & 蠤 數 & 寸 法 & 䣩 数 & 寸 法 & 䣩 数 & 寸 法 & 䤀 数 & 寸法 & 䣩 斯 & 寸法 & 䣩 数 \\
\hline \multicolumn{2}{|c|}{ (造船材料) } & 鄙 & 7,348 & $5+$ & 181 & \multicolumn{2}{|c|}{ 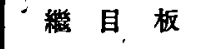 } & \multirow{2}{*}{$\frac{1 / 2}{3 / 4}$} & \multirow{2}{*}{$\begin{array}{l}\mathbf{3 7 7} \\
\mathbf{3 4 1} \\
\mathbf{5 2 1}\end{array}$} & \multicolumn{2}{|c|}{ 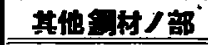 } \\
\hline $1 / 16$ & 2 & \multicolumn{2}{|c|}{ 銅板 $(0.7 \mathrm{~m} / \mathrm{m}$ 以下 $)$} & \multicolumn{2}{|c|}{ 錻 力 板 } & \multirow{4}{*}{\multicolumn{2}{|c|}{\begin{tabular}{|c|r|}
148 2lbs 用 & 4 \\
100 & 174 \\
82 & 24 \\
18 & 13 \\
12 & 7 \\
\end{tabular}}} & & & \multicolumn{2}{|c|}{ 特“珠 銈 } \\
\hline .24 & 29 & sheet a & & $100^{\mathrm{lbs}}$ & 920 & & & \multirow{7}{*}{$\begin{array}{l}11 / 4 \\
11 / 2 \\
13 / 4 \\
2 \\
25 / 2 \\
3 \\
31 / 2 \\
4\end{array}$} & \multirow{2}{*}{$\begin{array}{r}184 \\
204\end{array}$} & \multirow{5}{*}{\multicolumn{2}{|c|}{ 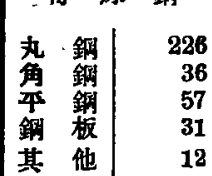 }} \\
\hline .25 & 13 & 7 & 10 & 170 & 732 & & & & & & \\
\hline .26 & 23 & 8 & 30 & Sheets & & & & & \multirow{2}{*}{$\begin{array}{r}6 \\
381 \\
142\end{array}$} & & \\
\hline 30 & 572 & 9 & 21 & 40 & 1 & \multirow{4}{*}{ 鲆 } & \multirow{2}{*}{222} & & & & \\
\hline 32 & $\mathbf{3 4}$ & 10 & 159 & 50 & 9 & & & & 167 & & \\
\hline 31 & 14 & 11 & 112 & 60 & 49 & & & & 33 & \multirow{3}{*}{\multicolumn{2}{|c|}{ 鲇 }} \\
\hline 36 & $\begin{array}{l}317 \\
137\end{array}$ & 12 & 30 & 70 & & & 1,145 & & 97 & & \\
\hline .38 & $\begin{array}{r}137 \\
60\end{array}$ & $\begin{array}{c}13 \\
\text { B.W.G.No. }\end{array}$ & 1,793 & $\begin{array}{l}80 \\
90\end{array}$ & $\begin{array}{l}13 \\
18\end{array}$ & \multicolumn{2}{|c|}{ 理杜人部 } & \multirow{3}{*}{$\begin{array}{l}41 / 2 \\
5 \\
6 \\
65 / 8\end{array}$} & \multirow{3}{*}{$\begin{array}{r}1 \\
26 \\
85 \\
149\end{array}$} & & \\
\hline-42 & 2 & 24 & 5 & 100 & 5 & \multirow{2}{*}{\multicolumn{2}{|c|}{ 線材 }} & & & & 輸 \\
\hline-44 & 74 & 26 & 25 & mixed & 242 & & & & & & \multirow[t]{2}{*}{122} \\
\hline 46 & 341 & 23 & 114 & Oil size & 2,243 & & & 7 & 46 & & \\
\hline $\begin{array}{l}.48 \\
.50\end{array}$ & $\begin{array}{r}2 \\
56\end{array}$ & $\begin{array}{l}\text { 3) } \\
\text { 33 }\end{array}$ & $\begin{array}{r}1,362 \\
8\end{array}$ & 其 他 & 699 & & 2 & 8 & 167 & \multicolumn{2}{|c|}{ 外輪及車帅 } \\
\hline$\cdot 54$ & 1 & 敦 & 3,669 & & 4,837 & $\begin{array}{l}\mathbf{5}^{m} / \mathrm{m} \\
\text { W.G.No. }\end{array}$ & & 9 & 10 & 鼓 & 3 \\
\hline $\begin{array}{l}\cdot 56 \\
.60\end{array}$ & $\begin{array}{r}3 \\
362\end{array}$ & 寃氣 & 識板 & 极合针 & 16,947 & $\begin{array}{l}6 \\
5\end{array}$ & $\begin{array}{r}596 \\
4690\end{array}$ & $\begin{array}{l}12 \\
24^{m} / m\end{array}$ & 12 & 其他合针 & 486 \\
\hline .625 & 5 & $0.014^{\prime \prime}$ & 502 & & & 4 & $\begin{array}{r}4,024 \\
51\end{array}$ & 32 . & 12 & 材裸针 & 43,045 \\
\hline $\begin{array}{r}66 \\
.68\end{array}$ & $\begin{array}{l}37 \\
15\end{array}$ & 0.017 & 236 & 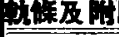 & 部 & 3 & $\mathbf{5 3}$ & 48 & 6 & & \\
\hline .69 & 6 & $\begin{array}{l}0.35^{m} / \mathrm{m} \\
0.50\end{array}$ & $\begin{array}{r}20 \\
143\end{array}$ & 軌 & 條 & $\begin{array}{l}2 \\
1\end{array}$ & $\begin{array}{l}45 \\
11\end{array}$ & 60 & $\begin{array}{l}1 \\
1\end{array}$ & E- & 1,221 \\
\hline $\begin{array}{l}\cdot 70 \\
.72\end{array}$ & $\begin{array}{r}12 \\
8\end{array}$ & 1.00 & 11 & $482 ! b s$ & 59 & 0 & 11 & $\begin{array}{r}76 \\
100\end{array}$ & $\begin{array}{r}8 \\
73\end{array}$ & プルーム & 52 \\
\hline .75 & 64 & 鼓 & 912 & $\begin{array}{l}82 \\
60\end{array}$ & 347 & 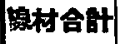 & 6,198 & 314 & 1 & ビレット & 583 \\
\hline $\begin{array}{l}\cdot 78 \\
.81\end{array}$ & $\begin{array}{r}109 \\
22\end{array}$ & & 板 & & $\begin{array}{r}21 \\
27 y\end{array}$ & & & 159 & $\overline{2}$ & 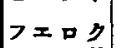 & \\
\hline .88 & 41 & $3 / 6^{\prime \prime}$ & 61 & & 347 & & 部 & Pitting & 18 & 口- 么其 & 222 \\
\hline 1 & 12 & $1 / 4$ & 98 & 其 他 & 180 & 鋼 & 管 & py Joir & 12 & & \\
\hline 計 & 2,414 & & 12 & 解 & 1,523 & $3 /{ }^{\prime \prime}$ & 29 & 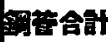 & 3,254 & スチール & 43 \\
\hline
\end{tabular}




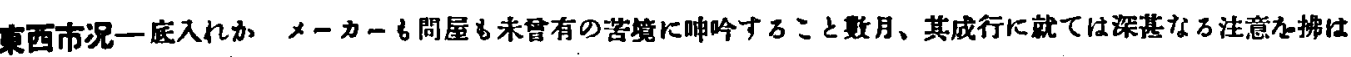

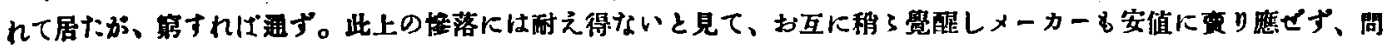

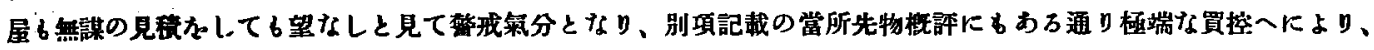

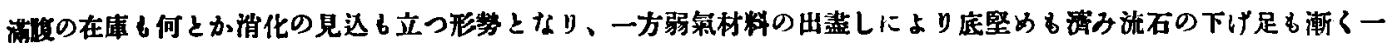
段落となつた模鉒く、ホットー息の形くおる。

来京市 珿

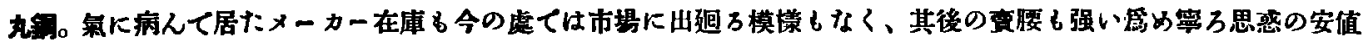

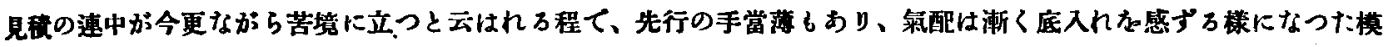

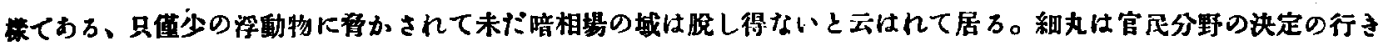

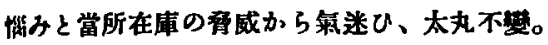

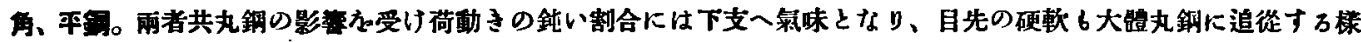
耤䚋されて居る。

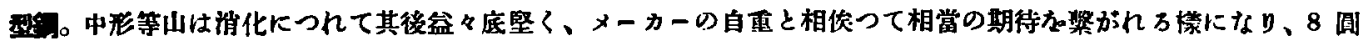

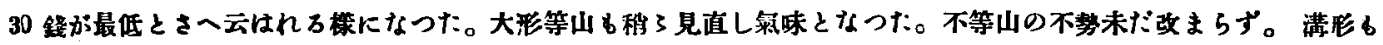
清石に昔の面影はなく高值のいのす平均さられて來だ。工形軟調不止。

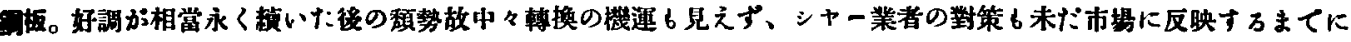
は到らはい楼漛ておる。

大䏒市況

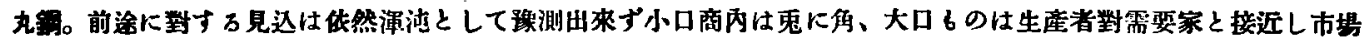
Кは何等影繁はない漛てある。

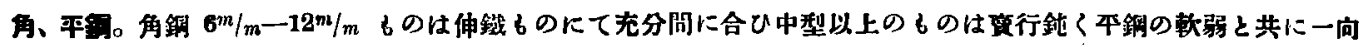

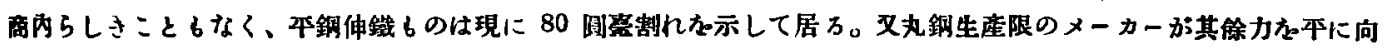
けんとして居ることる注目せられてかる。

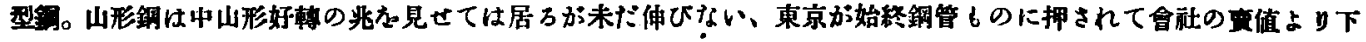

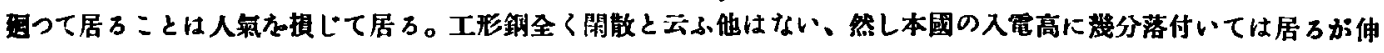

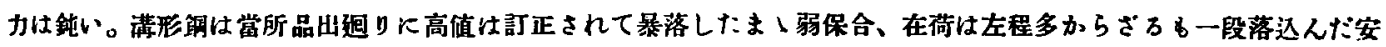

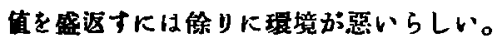

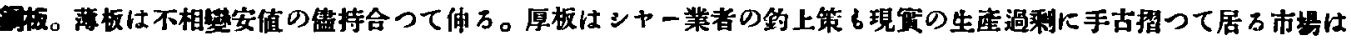
苦しはく90䟝各割つけ样くおる。

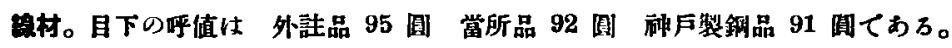

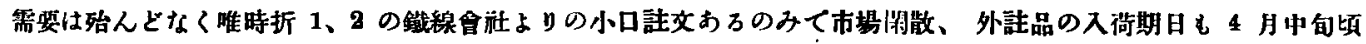
と見られてのろのて頭重ながら以上の值段て持合つてかる。

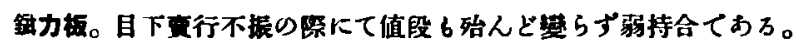

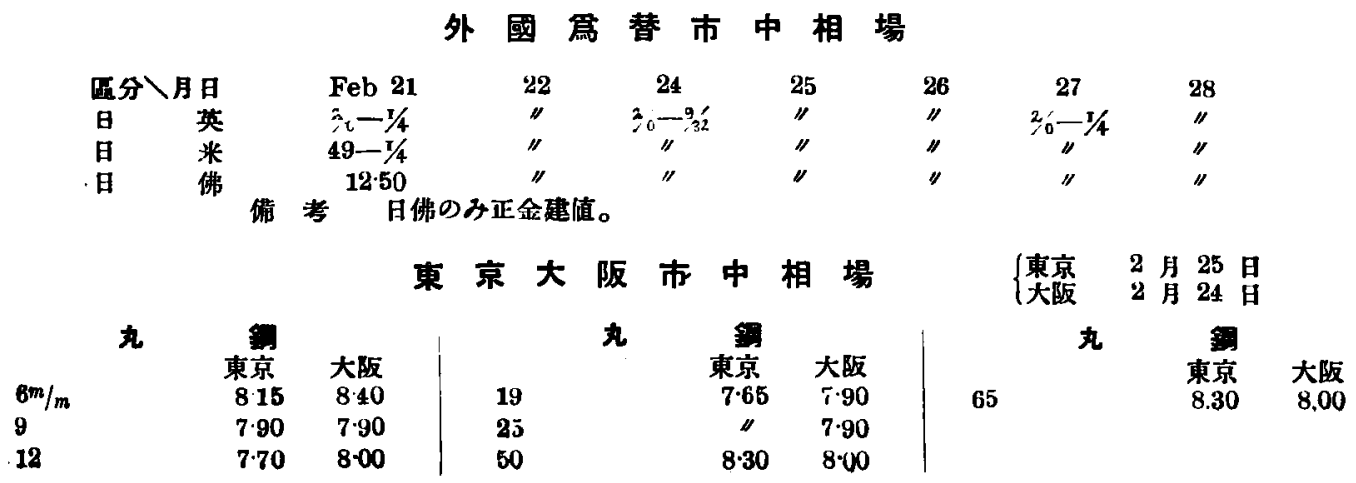




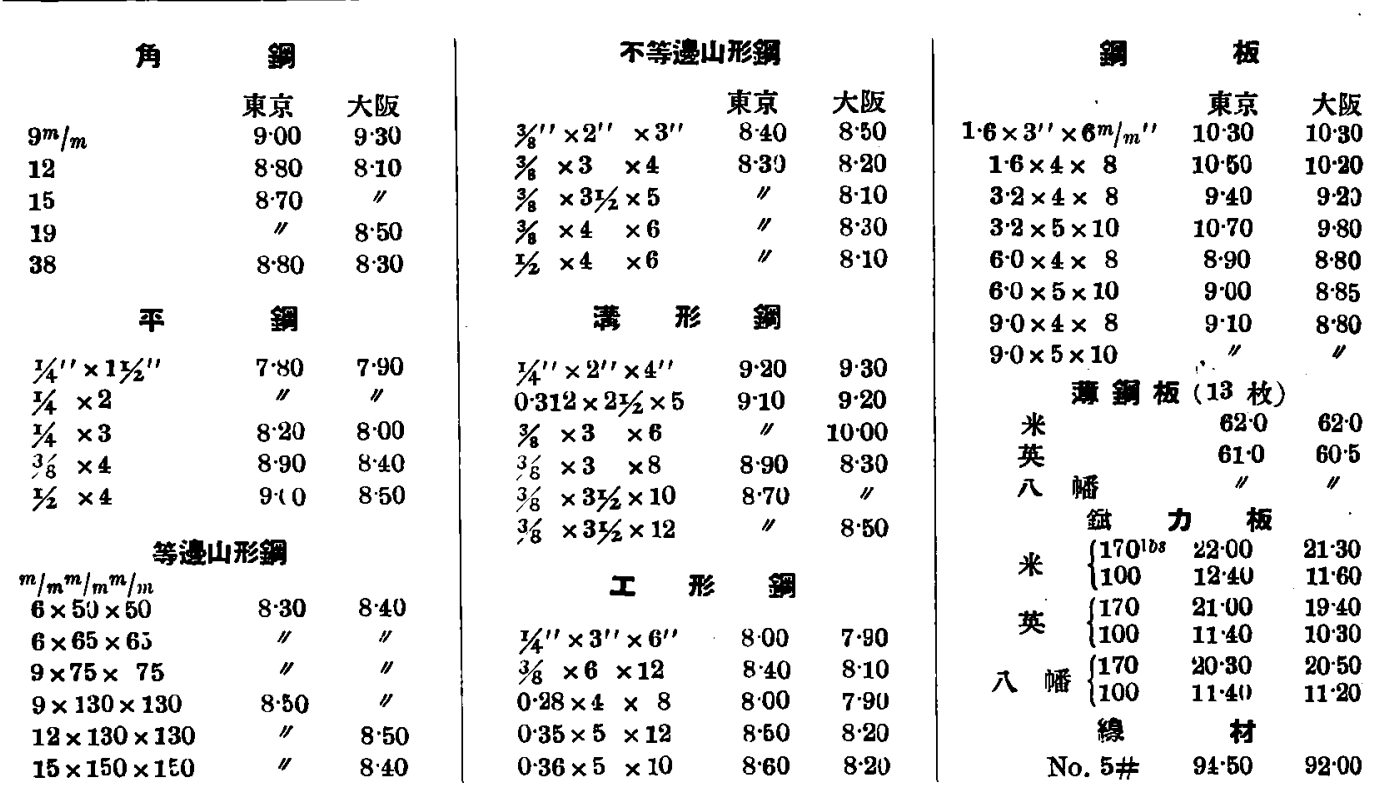

偖考 單位 $100 \mathrm{~kg}$ につ (置㘯渡值殷)、但し薄板は 1 枚當り。楾材は 1 䣩當り。錻力板は 1 箱當り。

12、1月渡定期先物皘殘數量表

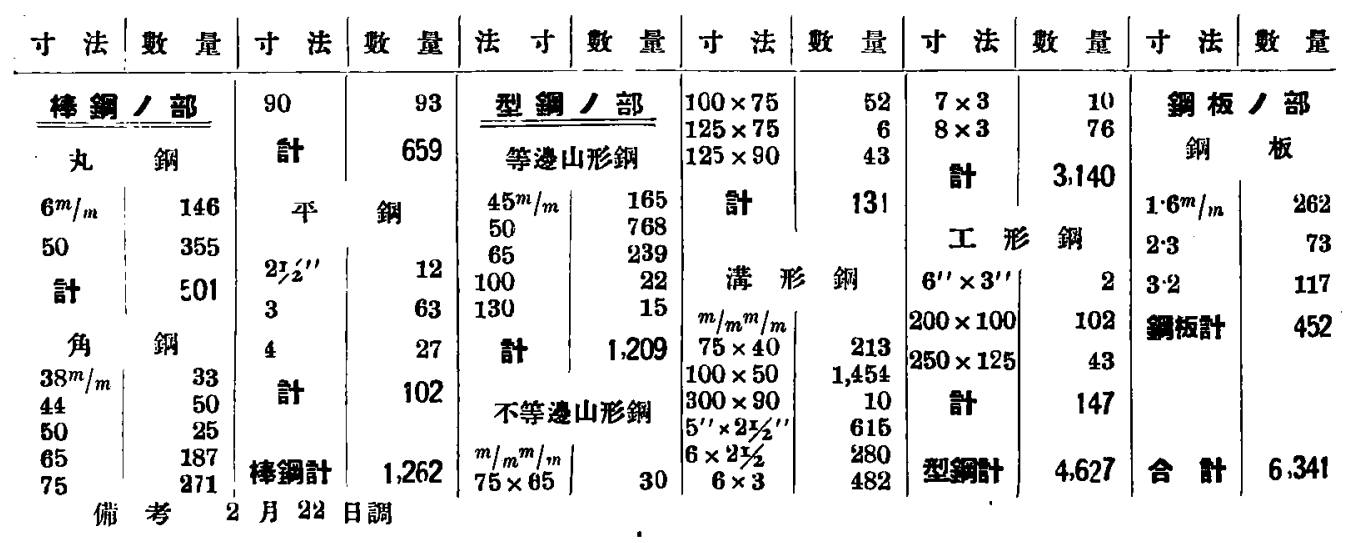

昭和 5 年 1 月棒鎆寸法別揚地別引渡高表單位䣩

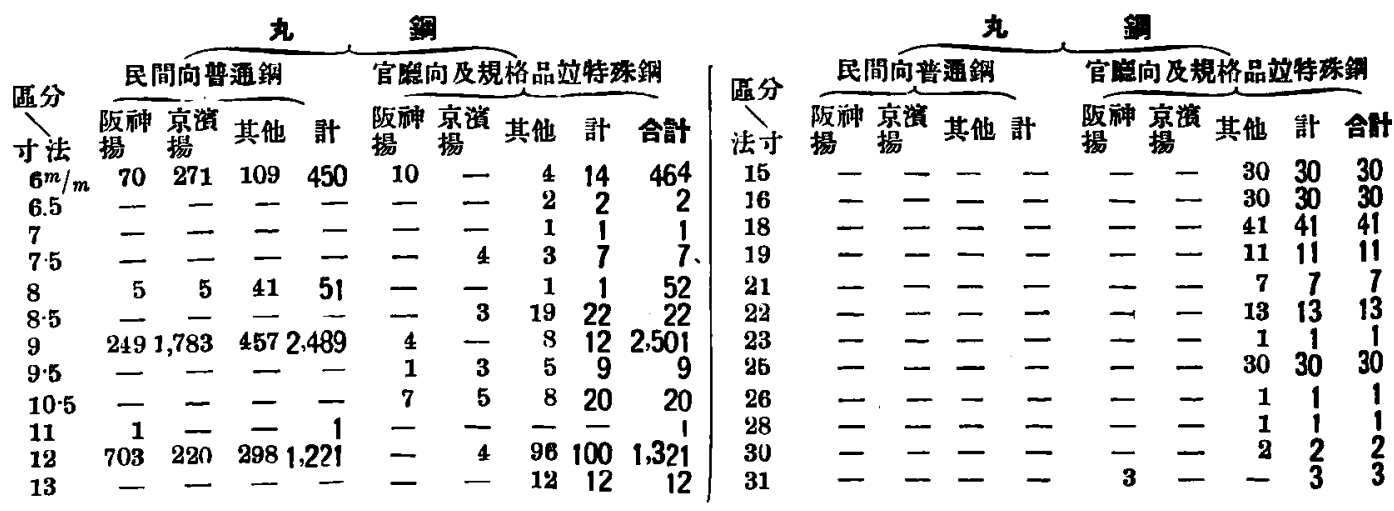




\begin{tabular}{|c|c|c|c|c|c|c|c|c|c|c|c|c|c|c|c|c|c|}
\hline \multirow{3}{*}{ 區分 } & & & 九 & \pm & & & & & & & & 角 & & 銅 & & & \\
\hline & \multicolumn{3}{|c|}{ 民間向普通銅 } & \multicolumn{5}{|c|}{ 官旺向及規恪品竝特殊銅 } & 區分 & \multicolumn{3}{|c|}{ 民閌向普通鈳 } & \multicolumn{5}{|c|}{ 官整向規格品立特珠銅 } \\
\hline & $\begin{array}{l}\text { 阪斻 } \\
\text { 掦 }\end{array}$ & $\begin{array}{l}\text { 索湲 } \\
\text { 㛫 }\end{array}$ & 其他 計 & $\begin{array}{l}\text { 阪神 } \\
\text { 揚 }\end{array}$ & 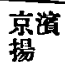 & 其他 & 晴 & 合計 & 开 & 恝垌 & 神京潧 & 其他郭 & 阪示 & 中高演 & 其他 & 計 & 合計 \\
\hline 31 & - & - & - & - & - & 64 & 64 & 64 & 75 & 揚 & - & - & 颃 & 场 & 8 & 8 & 8 \\
\hline 34 & - & - & -- & - & 2 & 2 & 4 & & 80 & 6 & - & - & - & 6 & - & 6 & 12 \\
\hline 35 & - & - & -- & - & 6 & - & 6 & 6 & 90 & 8 & - & - & - & - & - & 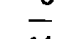 & 8 \\
\hline 36 & - & - & -- & - & 23 & 3 & 26 & 26 & 100 & - & -. & -- & - & 5 & 9 & 14 & 14 \\
\hline 38 & - & - & -- & - & 14 & 16 & 30 & 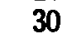 & ${ }^{1} 20$ & - & - & -- & - & - & 9 & 9 & 9 \\
\hline 40 & - & - & -- & - & $\overline{7}$ & 1 & 1 & ! & 195 & - & $\bar{z}$ & $-\overline{15}$ & - & 92 & - & $9 ?$ & 97 \\
\hline $\begin{array}{l}44 \\
48\end{array}$ & $\bar{z}$ & $\overline{-}$ & $=\overline{-}$ & 二 & 1 & 二 & 1 & 1 & 130 & 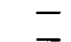 & 15 & $=15$ & $\overline{16}$ & 一 & $=$ & $\overrightarrow{16}$ & 15 \\
\hline 50 & 51 & 55 & 98207 & 1 & - & $\overline{14}$ & $\begin{array}{r}99 \\
15\end{array}$ & 9 & 0 & $=$ & 二 & $=-$ & 10 & - & $\overline{8}$ & 10 & 16 \\
\hline & $8 t$ & 30 & 8122 & - & - & 10 & 15 & 222 & $\begin{array}{l}140 \\
150\end{array}$ & 二 & $=$ & Z & Z & - & $\begin{array}{l}4 \\
9\end{array}$ & 2 & 2 \\
\hline 60 & & 4 & $12 i$ & 7 & - & 1 & 8 & is & 152 & - & - & - & 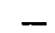 & 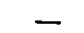 & 7 & 7 & 7 \\
\hline 65 & 157 & 65 & 70292 & 一 & - & 29 & 29 & 32 & 170 & - & - & -- & - & - & 21 & 21 & 21 \\
\hline 70 & 176 & 60 & 12249 & $\therefore$ & - & 5 & - & 2 & 角野 & 266 & 254 & 60580 & 16 & 104 & 84 & 204 & 784 \\
\hline & ? & 172 & & $\overline{0}$ & - & 9 & 9 & & 話 & 206 & 2,54 & $\pi$ & & & & & \\
\hline $\begin{array}{l}80 \\
90\end{array}$ & $\begin{array}{l}19 \\
98\end{array}$ & $\mathbf{4 0}$ & $\begin{array}{ll}17 & 36 \\
35 & 173\end{array}$ & 26 & 二 & 17 & $\begin{array}{r}3 \\
43\end{array}$ & 39 & & & & 平 & & 绸 & & & \\
\hline 100 & 112 & 80 & 9201 & - & 1 & 21 & 45 & 216 & 34 & 138 & 162 & 42342 & - & - & - & 一 & 342 \\
\hline 30 & - & - & -- & 3 & 二 & 46 & 4 & 4 & $i^{8}$ & 290 & $\begin{array}{r}65 \\
164\end{array}$ & $\begin{array}{l}9 \\
36499\end{array}$ & - & $=$ & $\overline{6}$ & 76 & \\
\hline & - & - & - & - & 2 & 14 & & & $11 / 4$ & - & 44 & & - & - & 1 & 1 & \\
\hline & - & - & - & 5 & - & & & & $1 x$ & 36 & 102 & $2816 j$ & 一 & - & $\mathbf{1}$ & 1 & \\
\hline 150 & - & - & -- & 一 & - & 6 & 6 & 7 & 134 & 70 & $\overline{5}$ & - & - & - & 3 & 2 & \\
\hline 160 & - & - & - & - & - & 7 & 7 & 8 & 2 & 589 & 211 & 848 & 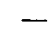 & - & $1 \overline{8}$ & 18 & \\
\hline & - & - & - & 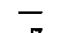 & - & 1 & 1 & 1 & $21 / 4$ & 130 & 122 & -2 & - & - & - & -9 & 5) \\
\hline & - & - & - & 7 & 一 & & 7 & 7 & & & & & & & & & \\
\hline 九舟 & 45 & 330 & 208 6.083 & 76 & 77 & 593 & 746 & 6,829 & $2 \pi / 2$ & 173 & 69 & 31273 & - & & 23 & 23 & \\
\hline & & & 章 & 鈃 & & & & & 3 & 323 & 194 & 20 & - & - & 19 & 19 & \\
\hline $12^{m}$ & & 50 & & & - & - & & & $3^{5}$ & 4 & 37 & 30 & - & - & - & - & \\
\hline It & & & & & & & & & & & & & - & - & 5 & & \\
\hline 19 & 2 & 10 & $\mathbf{3}$ & - & - & 4 & 4 & 3 & $\mathbf{b}$ & 133 & 328 & -466 & - & - & 11 & 11 & $4 / 7$ \\
\hline 32 & 20 & 35 & 1368 & & & & & 68 & & & & 19 & & & & & \\
\hline 38 & 81 & 42 & 123 & - & - & 9 & 9 & 132 & & & & 3114,640 & 1 & 0 & G2 & & 4,739 \\
\hline 44 & 27 & 28 & & - & 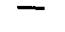 & 6 & $\overline{5}$ & 60 & & & & & & & & & \\
\hline $\begin{array}{l}50 \\
55\end{array}$ & 6 & $\begin{array}{l}40 \\
19\end{array}$ & $\begin{array}{l}29 \\
-133 \\
19\end{array}$ & - & $\overline{1}$ & - & $\begin{array}{l}b \\
1\end{array}$ & 20 & & 5003 & $47 P_{1}$ & 7911.300 & 93 & 181 & 769 & 12 & 35? \\
\hline & & & & & & & & & & & & & & & & & \\
\hline
\end{tabular}

販 置 旬報第 121 號 昭和 5 年 3 月 13 日

紫践所販輁部

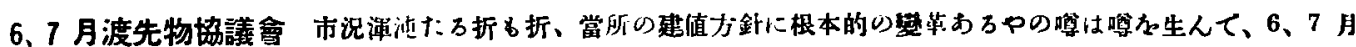
渡先物垛議會は 3 月 8 日緊張禡に東京出張所に於て開汃た。

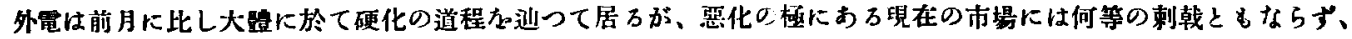

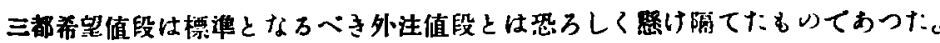

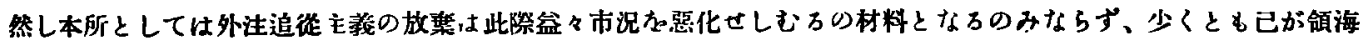

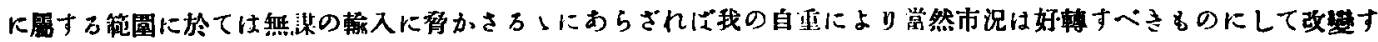

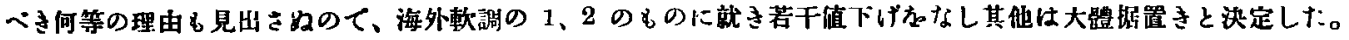

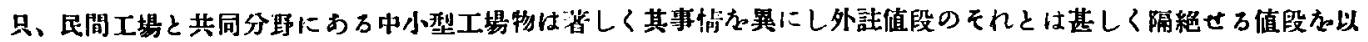

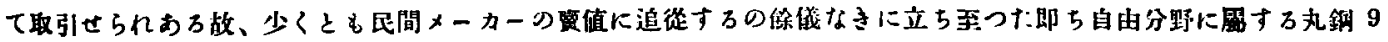

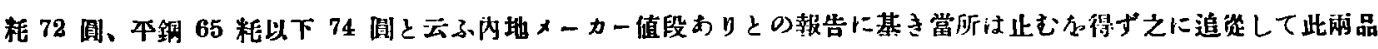

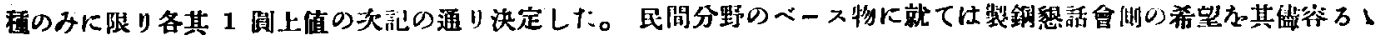

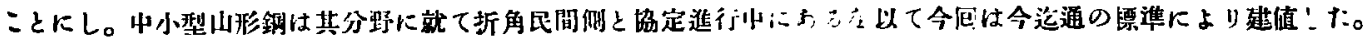

(13 日決裁)

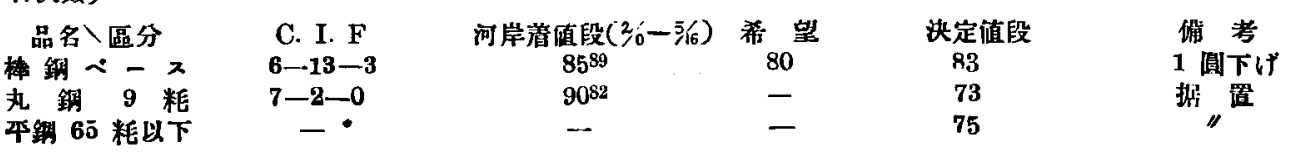


鐵 と鋼 第十六年 第三號

\begin{tabular}{|c|c|c|c|c|c|}
\hline 中小型山形銅 & $6-12-6$ & $85^{64}$ & 80 & 84 & 势 管 \\
\hline 大型山形鈎 & $6-12-6$ & $85^{64}$ & 80 & 84 & $"$ \\
\hline 工 形 鈎 & $6-10-0$ & $81^{43}$ & 80 & 83 & " \\
\hline 涉 形 (吋寸法) & $7-0-0$ & $89^{30}$ & 85 & 89 & 1 馆上け \\
\hline " (粕寸法) & $6-9-0$ & $83^{95}$ & 83 & 84 & 招置 \\
\hline 銅板 & $7-13-0$ & $95^{\mathrm{Gl}}$ & 90 & 94 & 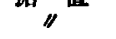 \\
\hline " 3.2 柾 & $7-16-6$ & 9731 & 92 & 97 & $"$ \\
\hline " $2 \cdot 3$ 籷 & $8-2-0$ & $104^{98}$ & 99 & 104 & " \\
\hline " 1.6 糖 & $8-4-0$ & $105^{93}$ & 100 & 105 & " \\
\hline & $7-8-6$ & $88^{02}$ & 86 & 87 & " \\
\hline 黑 䔳 銅 板 & $13-5-0$ & $159^{02}$ & 156 & 158 & 2 䝻下い \\
\hline 錻力 170 封度 & $1-17-6$ & 1980 & $\left\{\begin{array}{l}\text { 大除 } \mathbf{1 9}^{000} \\
\mathbf{1 9 5 0}\end{array}\right.$ & 1980 & 10衅市if \\
\hline " 100 封度 & $1-0-8$ & 1095 & $\left\{\begin{array}{l}\text { 笨笑 } 10^{550} \\
\text { 㟲 }\end{array}\right.$ & $10^{80}$ & 0 \\
\hline
\end{tabular}

2 月中の三港翰入

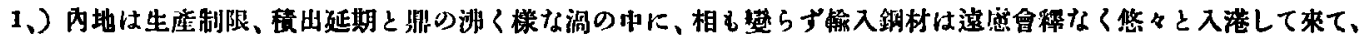

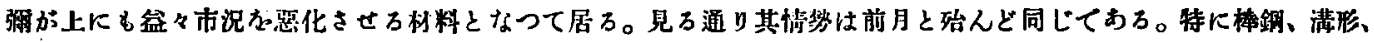

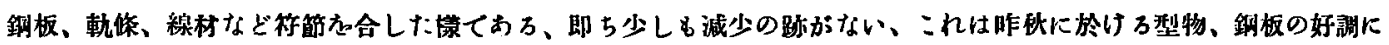

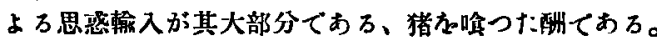

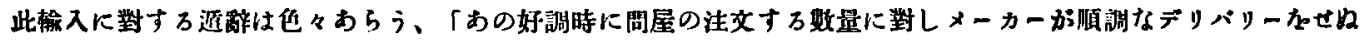

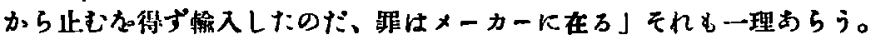

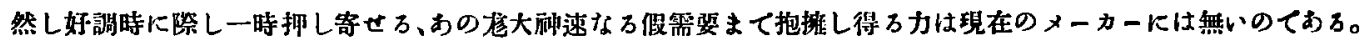

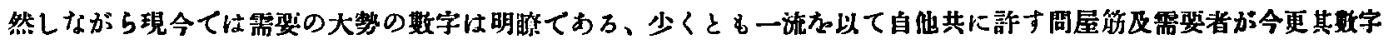

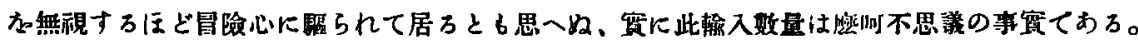

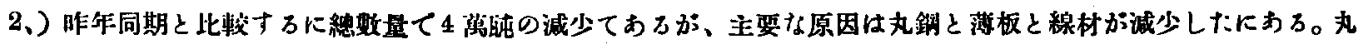

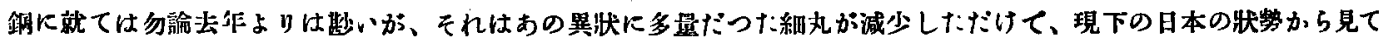

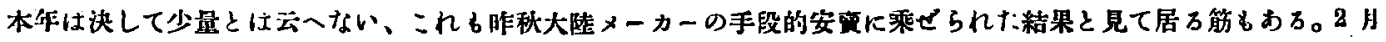

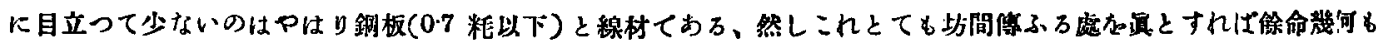

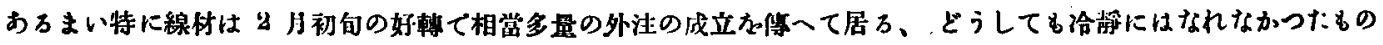
と見える。

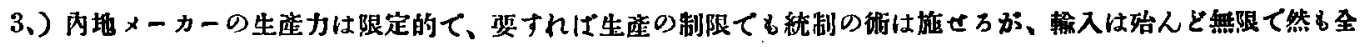
然盘統制てあ万、其處にも一つの閳題が㙛されて居万。

昭和 5 年 2 月中三港銅材軨入数量表單位䣩

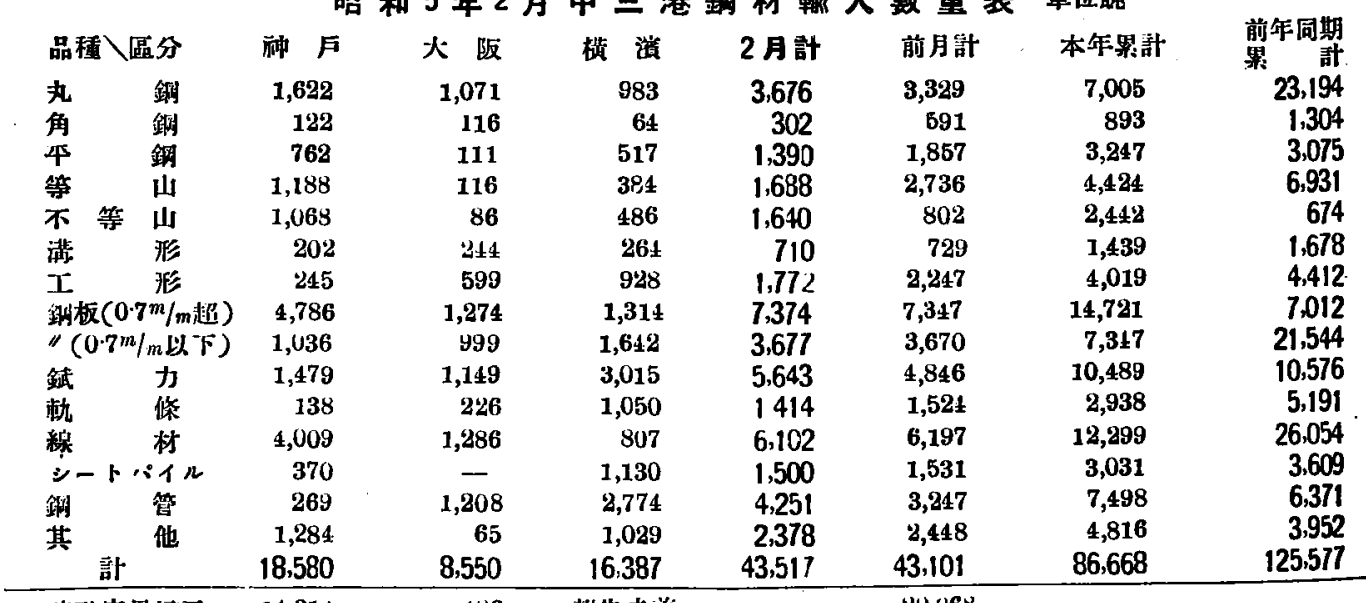

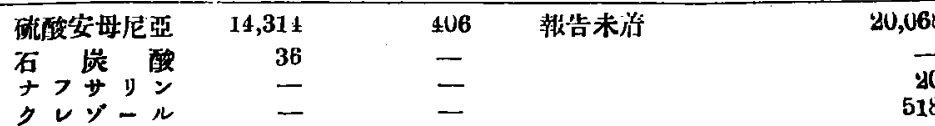

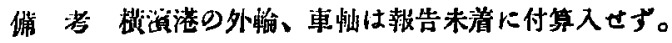


昭和 5 年 1 月中當所品種寸法別生産高

單位醋

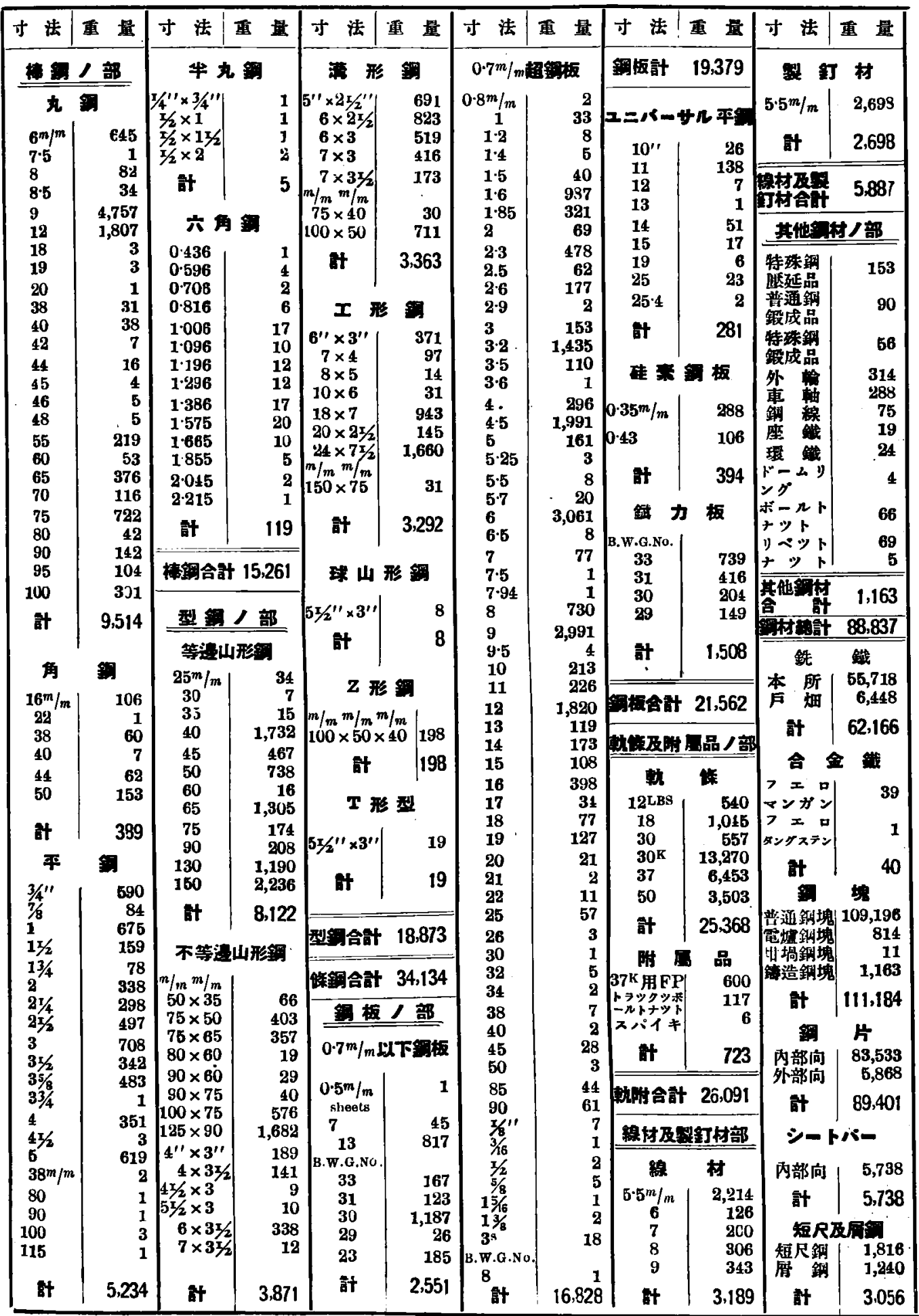




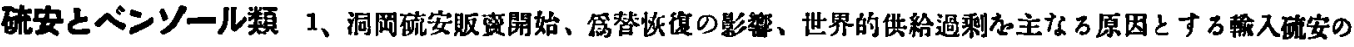

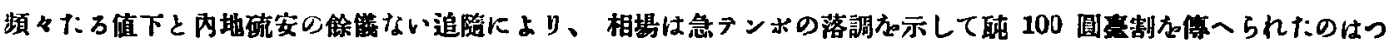

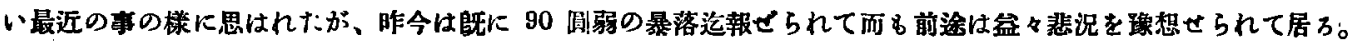

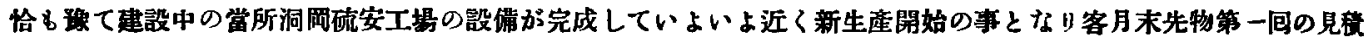

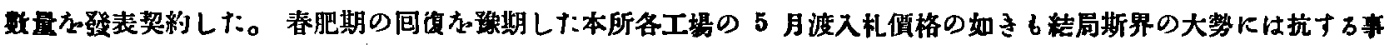

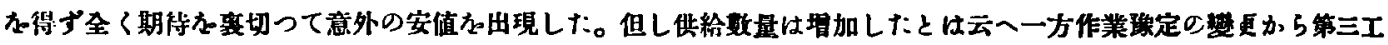

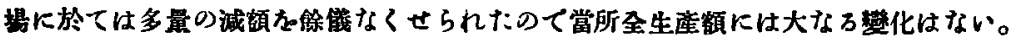

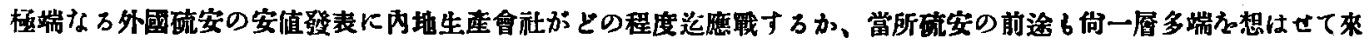

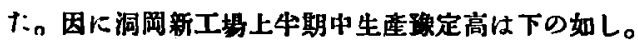

$\begin{array}{ccccccc}4 \text { 月 } & \text { 5月 } & 6 \text { 月 } & 7 \text { 月 } & 8 \text { 月 } & 9 \text { 月 } & \text { 計 } \\ 292 \text { 䣩 } & 302 \text { 䣩 } & 292 \text { 䎲 } & 302 \text { 䣩 } & 302 \text { 䣩 } & 292 \text { 䣩 } & 1.782 \text { 䣩 }\end{array}$

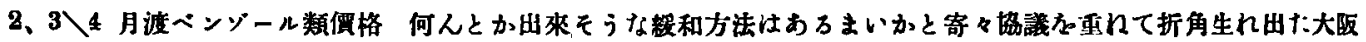

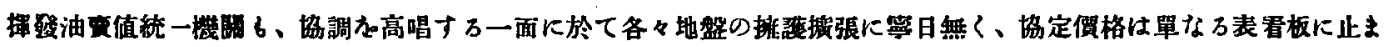

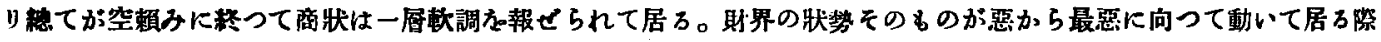

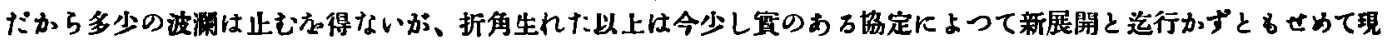
狀維持の原動カたらしもる事㤂期待したい。

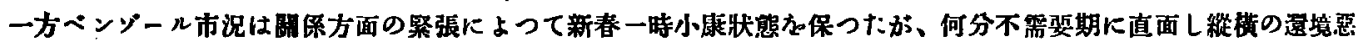

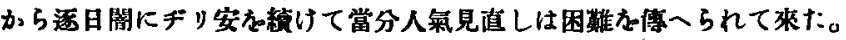

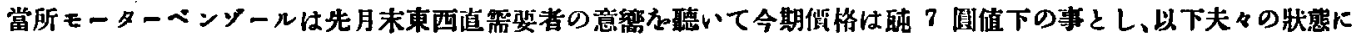

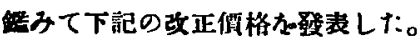

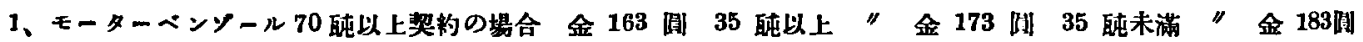

2、100\%ベンゾール 金 215 国]

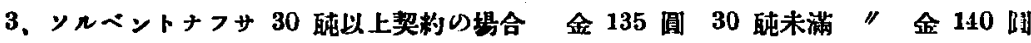

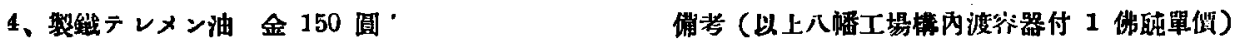

昭和 5 年 3 月上旬線材。薄板、鐡力板、輸入速報

\begin{tabular}{|c|c|c|c|c|c|}
\hline & & 村 & & 雨 & 鏠カ板 \\
\hline 區分 \品名 & B. T.G.KO. & 其 他 & 話 & 07 砘以下 & \\
\hline 桐 & 824 & 51 & 875 & 67 & 257 \\
\hline 阪 & 256 & - & 256 & 76 & - \\
\hline 䆏 & 1,058 & 102 & 1,160 & 408 & 655 \\
\hline 計 & 2,138 & 153 & 2.291 & 551 & 912 \\
\hline
\end{tabular}

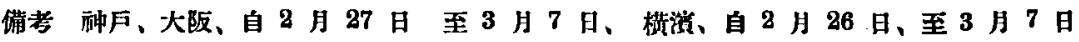

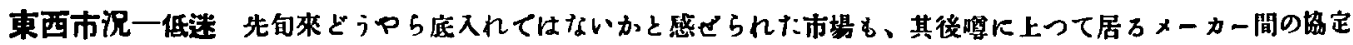

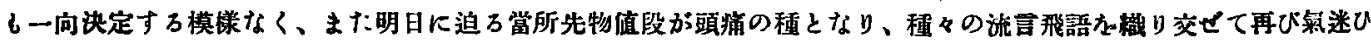

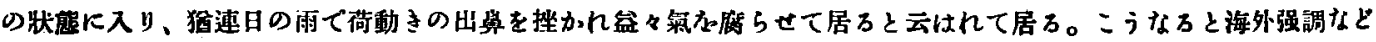

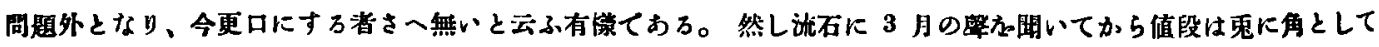

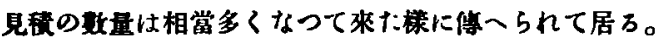

東 京市 況

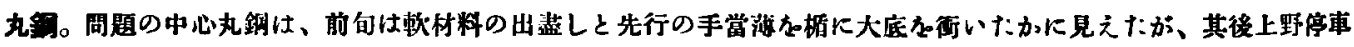

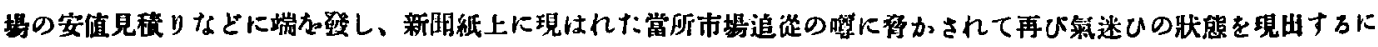

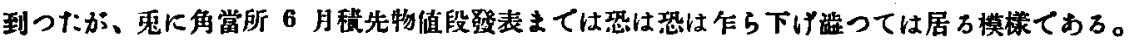

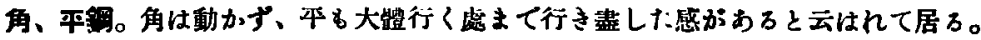

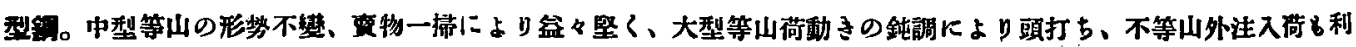

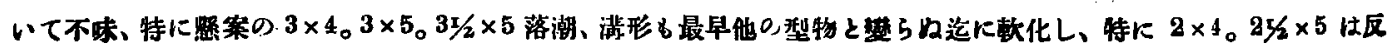




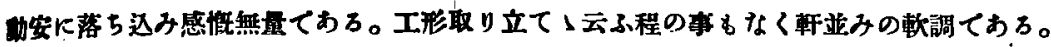

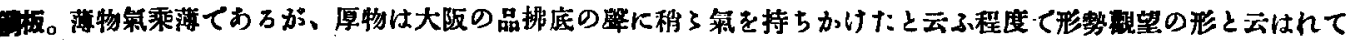
居乃。

大市況

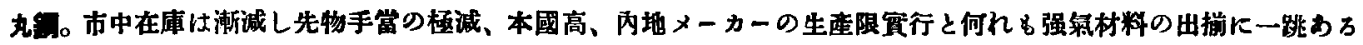
ベるところ財界四園の情况之れか不許、今斬くは所销忍苦時代と見られてわる。

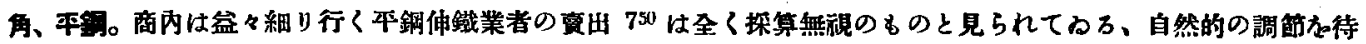

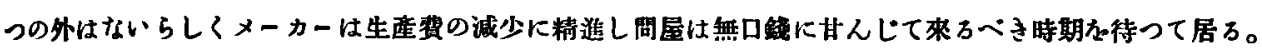

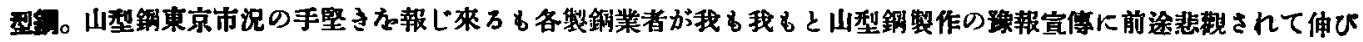

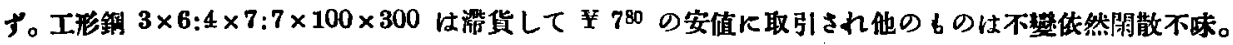

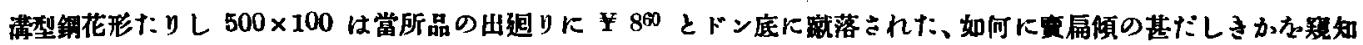
するに足万。其他の。のは大同小異の成行か示し真行又活氮なし。

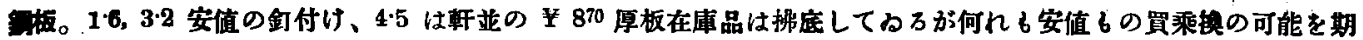

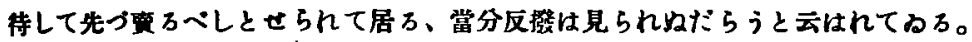

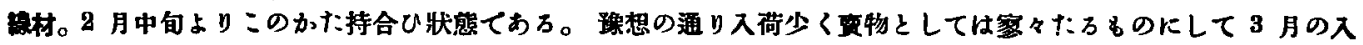

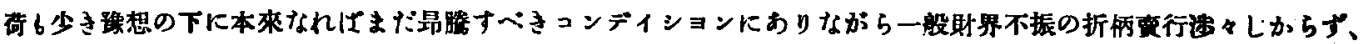

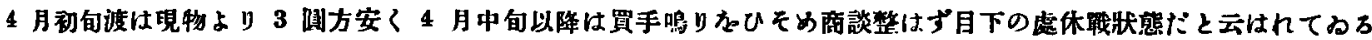

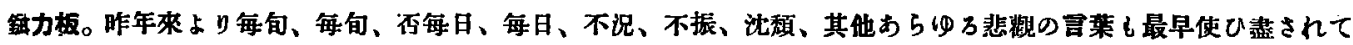

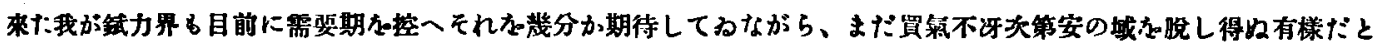
云はんてらら。

海外電報 2 月 26 日着在伯林長井商務㫪記官來奄

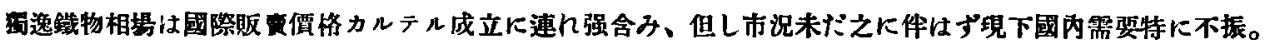

2 月 28 日着在倫敦松山商務寨事官來電

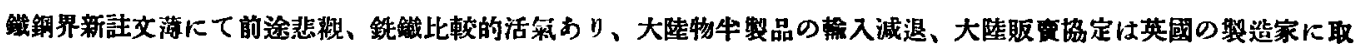

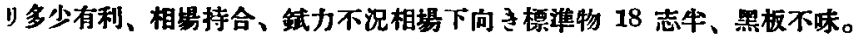

\section{外國篇替市中相場}

\begin{tabular}{|c|c|c|c|c|c|c|c|c|}
\hline 分入月日 & Mar 1st & 3rd & 4th & 5th & 6th & 7 th & 8th & Icth \\
\hline 英 & $3_{0}^{\prime}-1 / 4$ & & " & " & " & " & " & $"$ \\
\hline * & $49-1 / 4$ & $"$ & " & " & " & $"$ & $"$ & $"$ \\
\hline 佛 & 12.50 & $"$ & " & " & " & " & " & " \\
\hline
\end{tabular}

備考 日佛のみ正金建值。

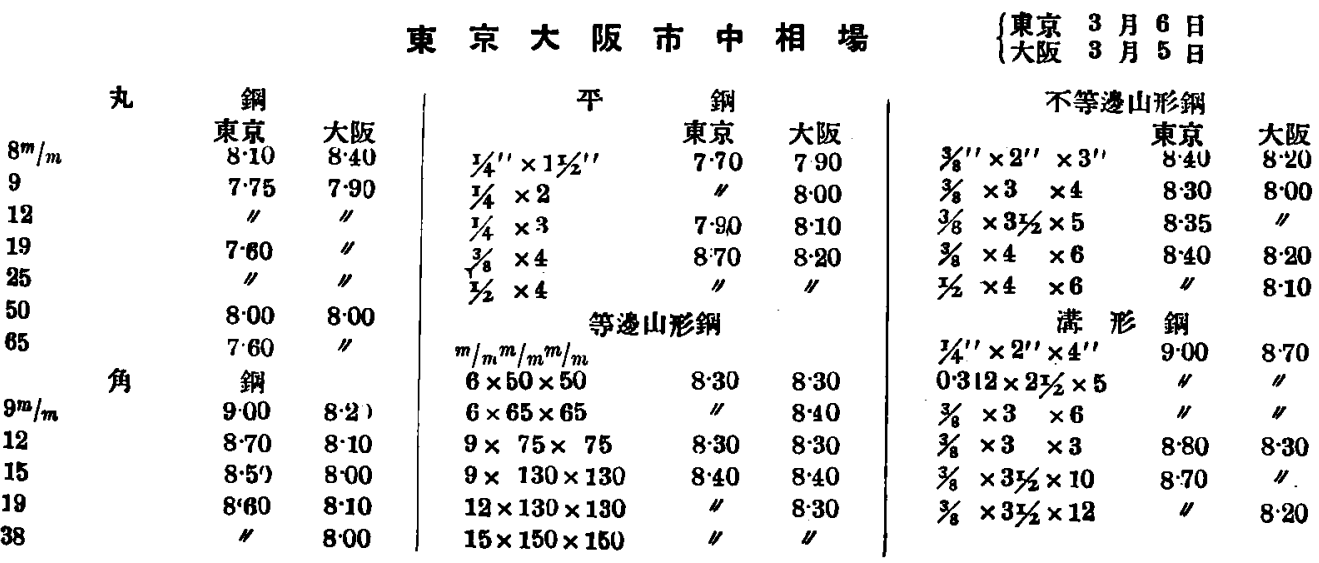


鐵 と鋼 第十六年 第三號

\begin{tabular}{|c|c|c|c|c|c|c|c|c|c|}
\hline I & 䤡 & & 鋼 & 板 & & \multicolumn{4}{|c|}{ 鐵力极 } \\
\hline $1 / 4^{\prime \prime} \times 3 " 1 \times 6$ & $\begin{array}{l}\text { 果景 } \\
7.90\end{array}$ & $\begin{array}{l}\text { 太阪 } \\
8.00\end{array}$ & $32 \times 5 \times 10$ & $\begin{array}{l}\text { 東京 } \\
10 \cdot 1\end{array}$ & 大阪 & & & 東京 & 大阪 \\
\hline $3 \times 6 \times 12$ & $8 \cdot 40$ & 8.20 & $6.0 \times 4 \times 8$ & 8.85 & 8.80 & 米 & 100 & $12 \cdot 40$ & 年 11.80 \\
\hline $0.28 \times 4 \times 8$ & 8.00 & $7 \cdot 80$ & $6.0 \times 5 \times 10$ & " & $"$ & 4 & 170 & 20.00 & 19.00 \\
\hline $35 \times 5 \times 12$ & $8 \cdot 40$ & 8.20 & $9.0 \times 4 \times 8$ & $9 \cdot 00$ & " & 央 & $\{100$ & $11 \cdot 40$ & $10 \cdot 70^{\circ}$ \\
\hline $36 \times 5 \times 10$ & $8 \cdot 50$ & $9 \cdot 30$ & $9.0 \times 5 \times 10$ & " & " & ת & $\{170$ & 21.00 & $20 \cdot 30$ \\
\hline 銅 & 板 & & & (13 枝 & & & & & \\
\hline $1.6 \times 3^{\prime \prime} \times 6^{m} / m^{\prime}$ & $10 \cdot 40$ & $10 \cdot 10$ & * & $62 \cdot 0$ & $62 \cdot 0$ & & 線 & 材 & \\
\hline
\end{tabular}

$\begin{array}{lll}1.6 \times 4 \times 8 & 10.60 & 10.00\end{array}$

$3 \cdot 2 \times 4 \times 8 \quad 930 \quad 9 \cdot 20$

$\begin{array}{ccc}\text { * } & 62 \cdot 0 & 62 \cdot 0 \\ \text { 英 } & 61.0 & 61 \cdot 0 \\ \text { 八 } & \text { " } & \text { " }\end{array}$

No. $5 \neq \quad 94.00 \quad 92.00$

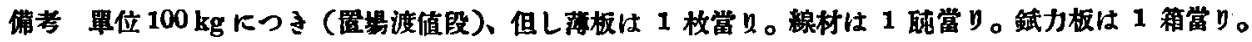

昭 和 5 年 2 月 分契䄪 高

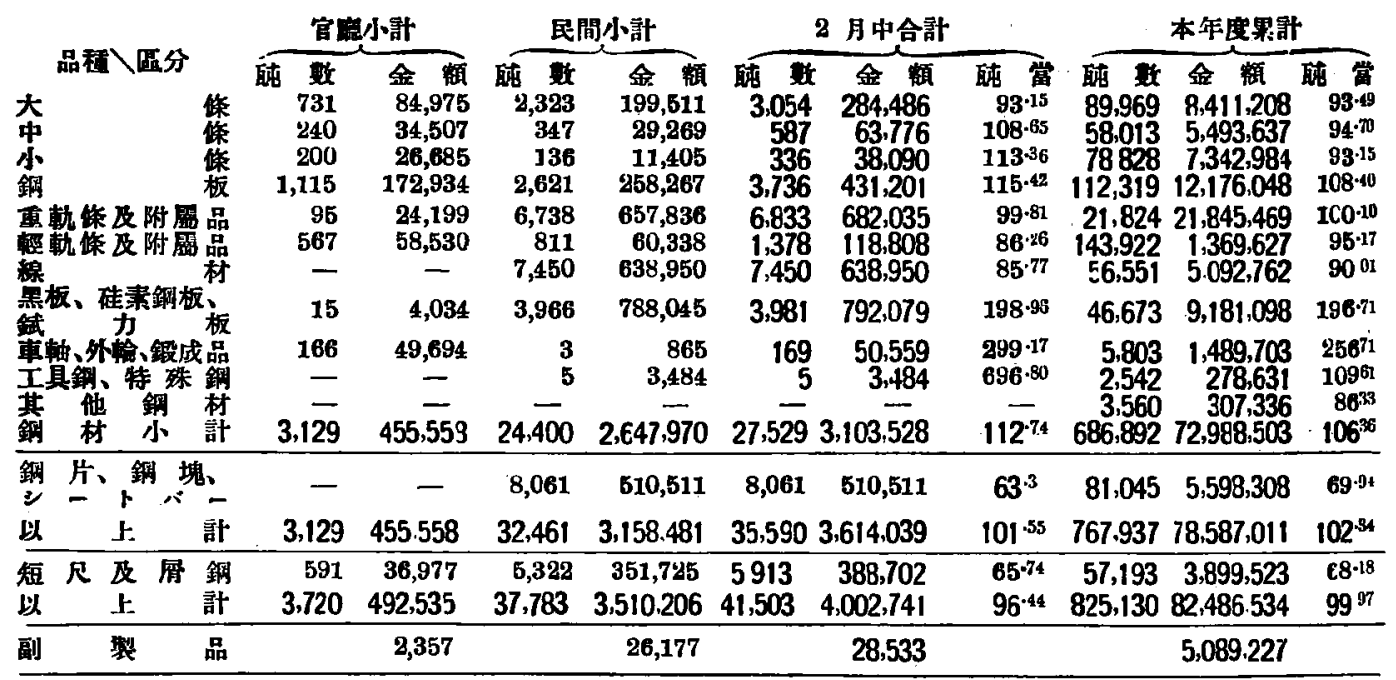

昭和 5 年 5 月渡定期先物品種寸法別数量表單位蠤

\begin{tabular}{|c|c|c|c|c|c|c|c|c|c|c|c|c|c|c|}
\hline 寸法 & 䣩数 & 累計 & 才法 & 䣩数 & 累計 & 寸法 & 砘数 & 界計 & 寸法 & 䣩数 & 累訴 & 寸 法 & 䣩 数 & 蝟 計 \\
\hline 九 & & 傢 & 角 & & 舵 & 平 & & 网 & & 息山开 & & & 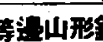 & \\
\hline $\begin{array}{l}m / m \\
8\end{array}$ & - & $\begin{array}{r}292 \\
118\end{array}$ & $16^{m / y} / m$ & 5 & $\begin{array}{l}79 \\
60\end{array}$ & $\begin{array}{l}32 \\
38\end{array}$ & $=$ & $\begin{array}{r}103 \\
67\end{array}$ & $\begin{array}{l}130 \\
150\end{array}$ & $\begin{array}{l}215 \\
315\end{array}$ & $\begin{array}{l}680 \\
881\end{array}$ & $\begin{array}{r}25 / 2 " \\
6 \times 322^{\prime \prime}\end{array}$ & 3 & $\begin{array}{r}23 \\
105\end{array}$ \\
\hline 9 & 60 & 1,659 & 25 & 5 & 82 & 44 & - & 41 & 200 & - & 100 & $6 \times 4$ & - & 276 \\
\hline 50 & 2 & 162 & 28 & 5 & $\begin{array}{l}5 \\
5 \\
5\end{array}$ & 65 & & 102 & & & & $75 \times 50$ & 10 & 10 \\
\hline & & 143 & 32 & 10 & 112 & 75 & 10 & 22 & & & & $75 x$ & 45 & \\
\hline 6 & - & $\begin{array}{l}36 \\
98\end{array}$ & $\begin{array}{l}54 \\
44\end{array}$ & 10 & 713 & $\begin{array}{r}90 \\
100\end{array}$ & 17 & 147 & & & & $100 \times 75$ & $M$ & \\
\hline 70 & 5 & 60 & 50 & - & 51 & & & & & & & $125 \times 75$ & - & \\
\hline & - & 88 & 65 & 24 & $5 i$ & 合㝇 & 79 & 1,451 & $\Delta t$ & 532 & 3114 & $\begin{array}{l}125 \times 90 \\
150 \times 10\end{array}$ & 43 & \\
\hline & - & $\begin{array}{l}45 \\
51\end{array}$ & $\begin{array}{l}75 \\
90\end{array}$ & - & $\begin{array}{l}54 \\
53\end{array}$ & & Dth & & DUT & 002 & 0,14 & & 112 & \\
\hline & - & 28 & & & & & & & & & 定 期 & 先 $4 \%$ & 合 it & \\
\hline & & 3 & 含鮕 & 75 & 786 & 45 & $=$ & $\begin{array}{l}208 \\
127\end{array}$ & 耻 & ? & - & 2,241 & $2,24 \mathrm{r}$ & 15,522 \\
\hline & 72 & 3.510 & & & & & $\overline{9}$ & 482 & & 板 & - & 544 & 544 & 2.916 \\
\hline & & & $\begin{array}{c}35 / 8 \\
19^{m} / m\end{array}$ & $\begin{array}{r}42 \\
5\end{array}$ & $\begin{array}{r}222 \\
90\end{array}$ & $\begin{array}{l}60 \\
75\end{array}$ & - & 235 & & 橦教 & - & 2,786 & 2,785 & 18.438 \\
\hline & & & $\begin{array}{l}22 \\
25\end{array}$ & - & $\begin{array}{r}67 \\
151\end{array}$ & $\begin{array}{r}90 \\
100\end{array}$ & $\overline{-}$ & 25 & & it & 11,008 & 7.435 & 18,438 & \\
\hline
\end{tabular}




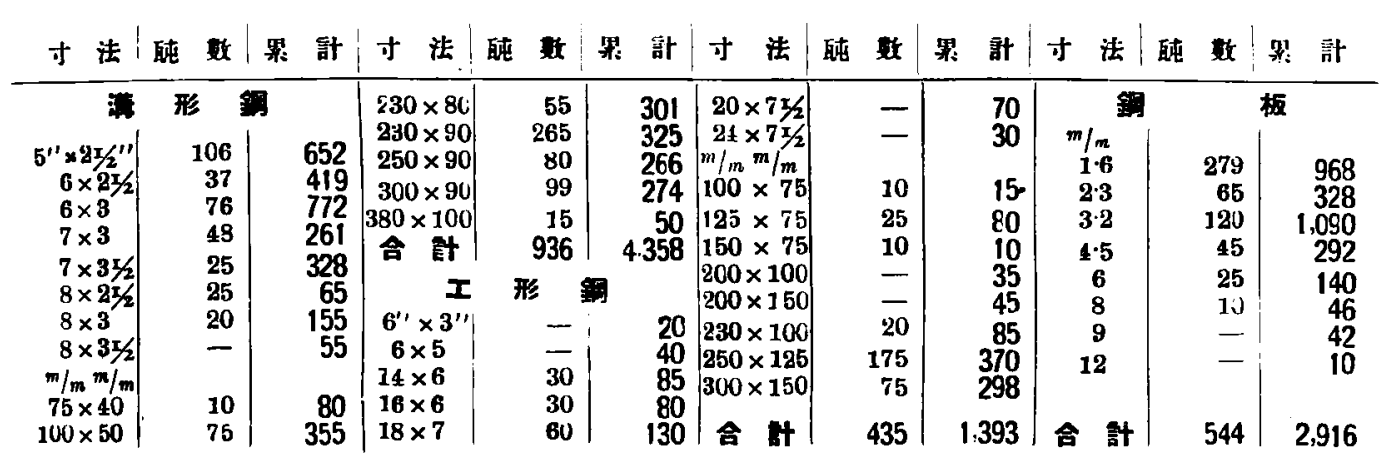

正誤

砂鐵鐿の狀態に關する研究 (著者訂正)

\begin{tabular}{|c|c|c|c|}
\hline 面 & 行 & 誤 & 正 \\
\hline 151 & $2-3$ & R. KOGAKUSHI MAEDA & R. MAEDA KOGAKUSHI \\
\hline$"$ & 10 & literatures are refrred & literatures are referred \\
\hline 152 & 23 & $\mathrm{Fe}_{2} \mathrm{TiO}_{8}$ はこれK晀才 & $\mathrm{Fe}_{2} \mathrm{TiO}_{4}$ はこれK盟才 \\
\hline 154 & 12 & $\mathrm{Fe}_{2} \mathrm{O}_{3}{ }^{\circ}$ 一の箘化は & $\mathrm{Fe}_{2} \mathrm{O}_{3}$ 一の酸化は \\
\hline 155 & 1 & 酸性鑯床に於ては & 䤇性鉿床に於ては \\
\hline 156 & 6 & Doclter & Doelter \\
\hline " & 8 & イシジム & イリジウム \\
\hline " & 10 & 五斯な深遥ささる & 瓦斯を唀ぜざ \\
\hline 157 & Table 1 & (此重の項) Polmer & Palmer \\
\hline 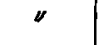 & Table 1 & (熔融鼔の項) $1350^{\circ}$ Yamada & $>1350^{\circ}$ Yamada \\
\hline 158 & Table 2 & (熔監點の項) Internat. crit. Table & Internat, Crit. Table \\
\hline 159 & 5 & Amer. Iron Steel Ind. & Amer. Iron Steel Inst. \\
\hline 162 & 30 & 70 青森縣下北郡野牛百尺首密石 & （野牛百尺層を除く） \\
\hline 163 & 3 & R. kïch & R. Küch \\
\hline$"$ & 16 & Broderick: Eidem & Broderick: idem \\
\hline 164 & 6 & Zeit. Krist. Min. 20 (1890) & Zeit. Krist. Min. 20 (1892) \\
\hline$\Delta$ & 41 & G. R. Fittler & G. R. Fitterer \\
\hline Table 2 & 10 & Tredestrond & Tredestrand \\
\hline • & 20 & Ural Ekersund & (Ural 走除了) \\
\hline 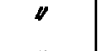 & 38 & Smith place, N-Cal. & Smith place. N. C. \\
\hline$"$ & 55 & (比重の項へ捕入) & 4:288 \\
\hline " & 56 & " & $4 \cdot 249$ \\
\hline$"$ & 57 & $"$ & $4 \cdot 410$ \\
\hline " & 59 & $"$ & $4 \cdot 520$ \\
\hline " & 74 & 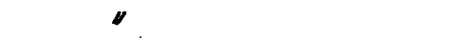 & $4 \cdot 240$ \\
\hline " & " & (拆入) & Villeneuve-en-Montagne, France \\
\hline
\end{tabular}


昭和 5 年 1 月中國別輸入数量表(單位砘)

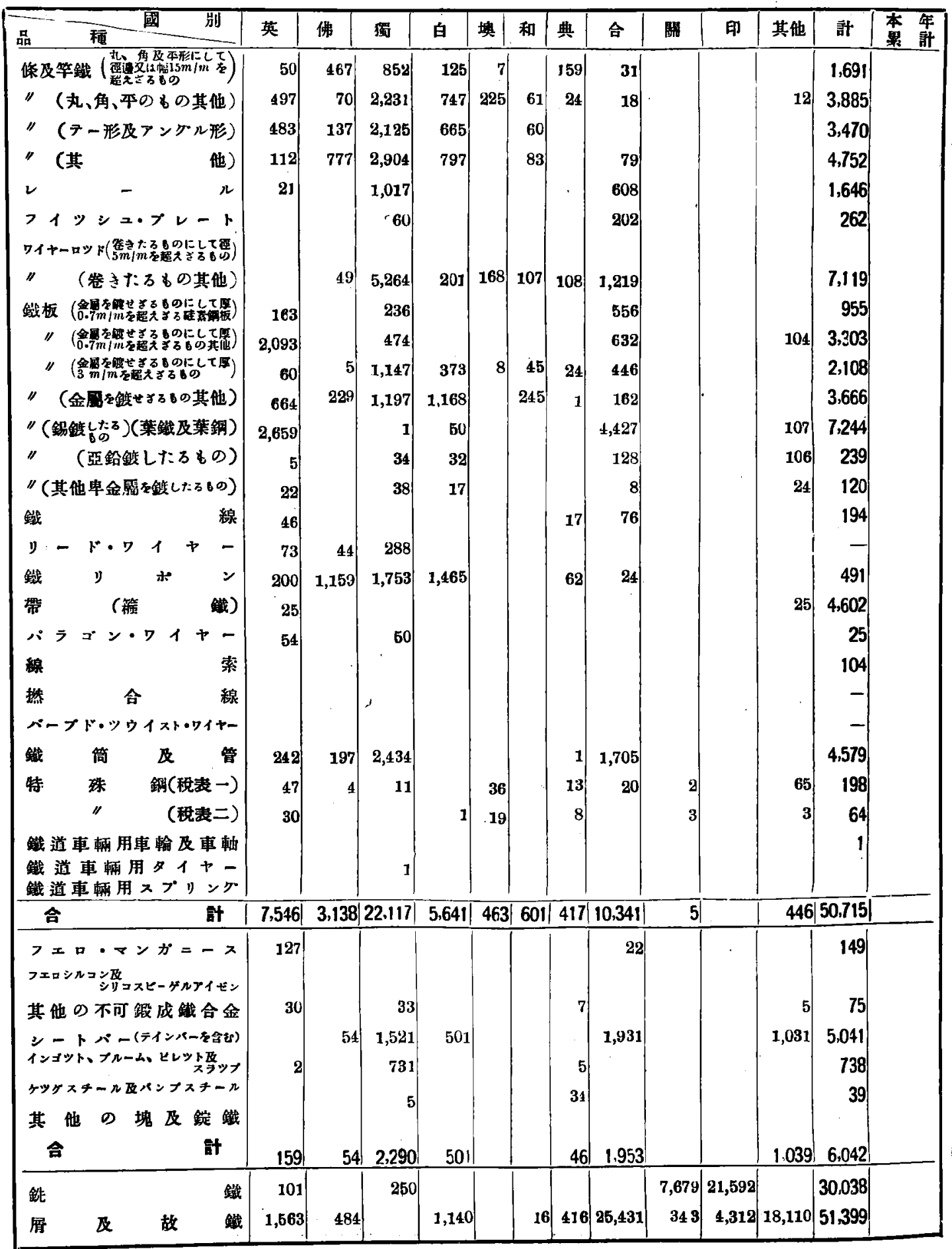

